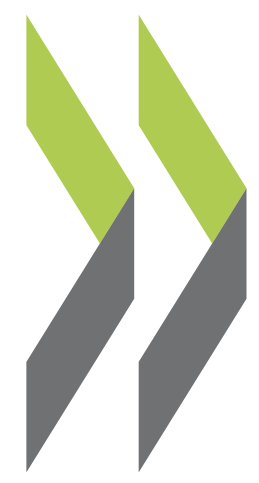

OECD Economics Department Working Papers No. 1162

Promoting the Financing of SMEs and Start-ups in Korea

Randall S. Jones, Myungkyoo Kim 
Organisation de Coopération et de Développement Économiques

Organisation for Economic Co-operation and Development

16-Sep-2014

ECONOMICS DEPARTMENT

English - Or. English

PROMOTING THE FINANCING OF SMES AND START-UPS IN KOREA

ECONOMICS DEPARTMENT WORKING PAPERS No. 1162

By Randall S. Jones and Myungkyoo Kim

OECD Working Papers should not be reported as representing the official views of the OECD or of its member countries. The opinions expressed and arguments employed are those of the author(s).

Authorised for publication by Alvaro Pereira, Director, Country Studies Branch, Economics Department.

All Economics Department Working Papers are available through OECD's Internet website at http://www.oecd.org/eco/workingpapers

Complete document available on OLIS in its original format

This document and any map included herein are without prejudice to the status of or sovereignty over any territory, to the delimitation of international frontiers and boundaries and to the name of any territory, city or area. 
OECD Working Papers should not be reported as representing the official views of the OECD or of its member countries. The opinions expressed and arguments employed are those of the author(s).

Working Papers describe preliminary results or research in progress by the author(s) and are published to stimulate discussion on a broad range of issues on which the OECD works.

Comments on Working Papers are welcomed, and may be sent to the Economics Department, OECD, 2 rue André-Pascal, 75775 Paris Cedex 16, France, or by e-mail to econ.contact@oecd;org.

This document and any map included herein are without prejudice to the status of or sovereignty over any territory, to the delimitation of international frontiers and boundaries and to the name of any territory, city or area.

The statistical data for Israel are supplied by and under the responsibility of the relevant Israeli authorities. The use of such data by the OECD is without prejudice to the status of the Golan Heights, East Jerusalem and Israeli settlements in the West Bank under the terms of international law.

\section{(C) OECD (2014)}

You can copy, download or print OECD content for your own use, and you can include excerpts from OECD publications, databases and multimedia products in your own documents, presentations, blogs, websites and teaching materials, provided that suitable acknowledgment of OECD as source and copyright owner is given. All requests for commercial use and translation rights should be submitted to rights@oecd.org 


\section{ABSTRACT/RÉSUMÉ \\ Promoting the financing of SMEs and start-ups in Korea}

The Korean government has made fostering a "creative economy" a top priority. The goal is to shift Korea's economic paradigm to one based on innovation in which new start-ups and venture businesses play a key role. However, the venture capital market is still at an early stage of development. To make venture investment a growth driver, it is important to expand the role of business angels, activate the merger-andacquisition market and foster entrepreneurship. A creative economy also depends on making SMEs, which account for $87 \%$ of employment, more dynamic. The productivity gap between large firms and SMEs, which benefit from a wide range of public support, is widening. SME policies should be streamlined and improved to promote market-based financing and reduce the negative effects of government funding programmes, which discourage the expansion of SMEs.

This Working Paper relates to the 2014 OECD Economic Survey of Korea (www.oecd.org/eco/surveys/economic-survey-korea.htm)

JEL classification: L25, L26, M13.

Keywords: Korea, creative economy, venture capital investment, venture business, business angels, startups, SMEs, credit guarantees, KONEX, KOSDAQ, crowd-funding, IPOs, mergers and acquisitions, nontangible collateral, entrepreneurship.

\section{Promouvoir le financement des PME et des jeunes entreprises en Corée}

Le gouvernement coréen a érigé en priorité la promotion d'une "économie créative ». L'objectif est que la Corée adopte un nouveau paradigme économique fondé sur l'innovation, suivant lequel les jeunes entreprises et les entreprises à risque joueraient un rôle clé. Le marché du capital-risque est cependant encore à un stade précoce de son développement. Pour que l'investissement en capital-risque soit vecteur de croissance, il est primordial de renforcer le rôle des investisseurs providentiels, de développer le marché des fusions-acquisitions et de favoriser l'entrepreneuriat. Une économie créatrice est aussi une économie qui dynamise les PME, lesquelles représentent $87 \%$ de l'emploi. L'écart de productivité entre les grandes entreprises et les PME, qui bénéficient d'un large éventail d'aides publiques, se creuse. Les politiques en faveur des PME doivent être rationnalisées et optimisées pour promouvoir les financements de marché et atténuer l'impact négatif des aides publiques, qui n'incitent pas les PME à se développer.

Ce Document de travail a trait à l'Étude économique de l'OCDE de la Corée, 2014 (www.oecd.org/fr/eco/etudes/coree.htm).

Classification JEL : L25, L26, M13.

Mots clés : Corée, économie créative, investissements en capital-risque, entreprises à risque, investisseurs providentiels, jeunes entreprises, PME, garanties de crédit, KONEX, KOSDAQ, financement participatif, introductions en bourse, fusions et acquisitions, garantie non tangible, entrepreneuriat. 


\section{TABLE OF CONTENTS}

PROMOTING THE FINANCING OF SMES AND START-UPS IN KOREA ...................................... 5

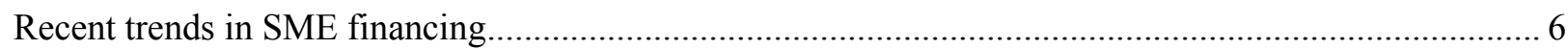

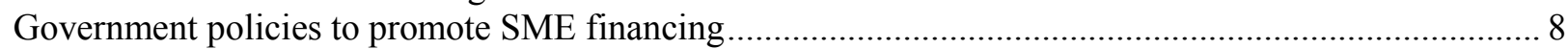

Direct financial support through the government and public institutions.......................................... 8

Regulatory measures and moral suasion on financial institutions ................................................... 10

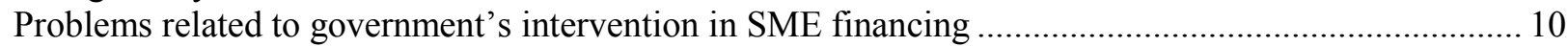

Generous government support has caused distortions ..................................................................... 11

Government financial support for SMEs has little impact on their performance ................................ 15

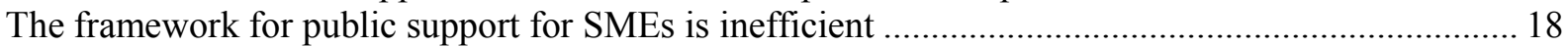

The venture capital market is at an early stage of development.......................................................... 19

The government's plan for a "creative economy" by strengthening the role of ventures and SMEs ........ 22

Establishing a virtuous cycle of growth in the venture business and start-up sector............................. 24

Expanding infrastructure for venture businesses and start-ups......................................................... 26

Policy recommendations for improving financing for SMEs and venture businesses ............................. 27

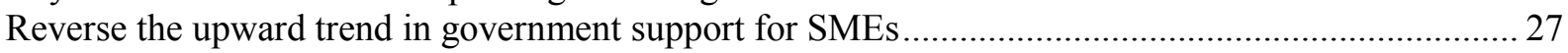

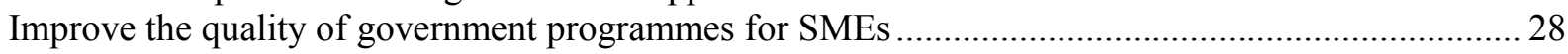

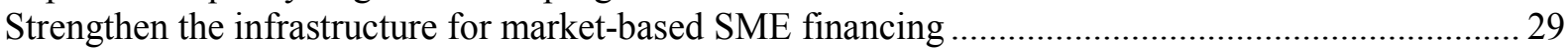

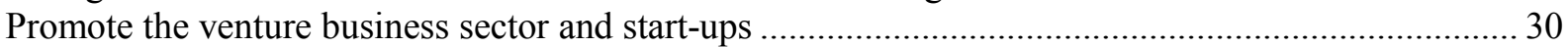

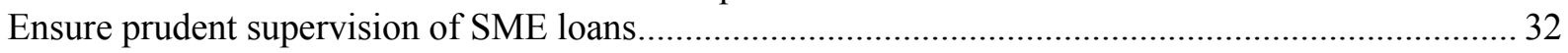

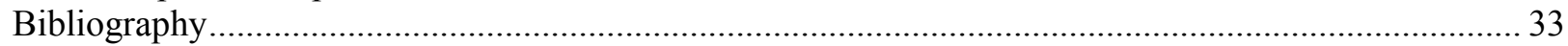

\section{Tables}

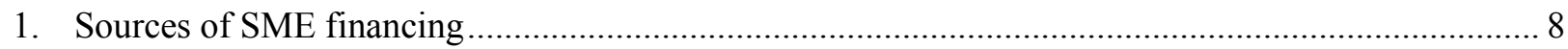

2. Firms receiving public financing support and guarantees ........................................................... 14

3. The impact of public financial support for SMEs on their performance …....................................... 16

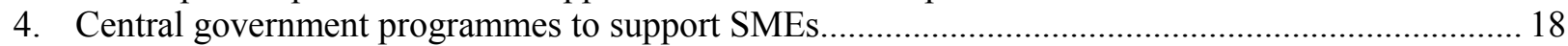

5. New programmes to promote a creative economy ......................................................................... 24

\section{Figures}

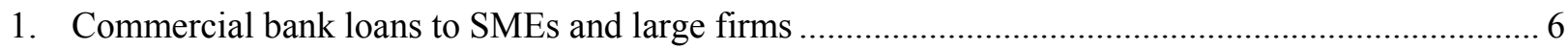

2. Banks' lending attitudes towards SMEs, large firms and households ............................................. 7

3. The framework of SME financing support in Korea ...................................................................... 9

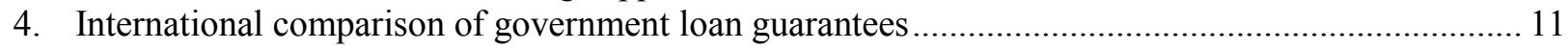

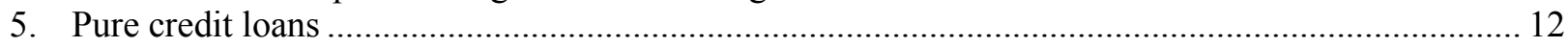

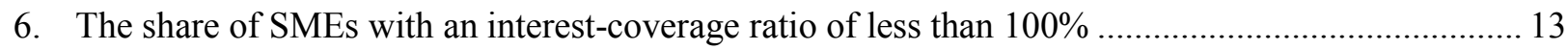

7. Korea has experienced a sharp drop in the number of bankruptcies ............................................ 13

8. The share of government financial support given to SMEs according to the age of the firm ............ 14

9. The shares of government guarantees that are long term and large in value...................................... 15

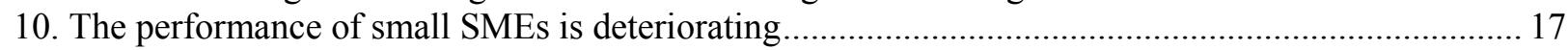

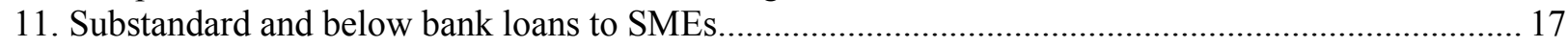

12. Korea's venture capital market has rebounded in recent years ......................................................... 20

13. International comparison of venture capital investment .................................................................. 20

14. The May 2013 Measures to improve the venture start-up ecosystem ........................................... 22

15. Korean SMEs account for a large share of banks' corporate lending ............................................... 27

\section{Boxes}

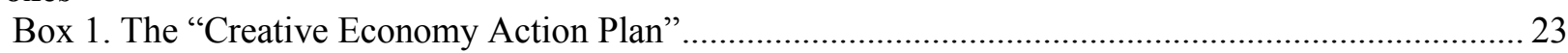

Box 2. Summary of recommendations to promote the financing of SMEs and start-ups in Korea .......... 32 
ECO/WKP(2014)58

\title{
PROMOTING THE FINANCING OF SMES AND START-UPS IN KOREA
}

\author{
By Randall S. Jones and Myungkyoo Kim ${ }^{l}$
}

1. Korea has grown from one of the poorest countries in the world in the 1950s to an advanced industrial economy today. Development was driven by government policies to promote exports, which forced firms to compete in the global market, and by the fast growth of large companies, especially those in the business groups known as chaebols. However, as the economy has narrowed the gap with the most advanced economies, this growth model is facing challenges. Strong competition with emerging economies, notably China, in low and medium-end markets, and with advanced economies in high-end markets is making it more difficult for Korea to further expand its global market share. In addition, the trickle-down effect from exports has declined. In 1998, 1 billion KRW of exports generated value-added of 0.65 billion KRW and 19 jobs. By 2010, the impact, adjusted for inflation, had fallen to 0.56 billion KRW of value-added and 7.9 jobs (Bank of Korea, 2012a). It is thus necessary to find new drivers of growth to complement exports and large companies, which account for around two-thirds of Korea's exports.

2. In addition, Korea's growth strategy has created equity challenges by increasing the gap between large companies and small and medium-sized enterprises (SMEs), which are more focused on the domestic market and less involved in international trade. SMEs, defined in the manufacturing sector as companies with less than 300 workers, accounted for $99.9 \%$ of registered firms in 2011 and $87 \%$ of employment. ${ }^{2}$ Indeed, output per worker in SMEs fell from 33\% of large companies in 2000 to 28\% by 2011 (Small and Medium Business Administration, 2013). In addition to lower wages, workers in SMEs face poorer working condition and less protection by the social safety net (2014 OECD Economic Survey of Korea).

3. To address these challenges, the government has long supported SMEs as a potential growth engine. In particular, it has provided financial support by supplying public funds directly to SMEs and by guaranteeing loans from private financial institution to SMEs since 1979. In addition, it uses moral suasion to encourage financial institutions to lend to SMEs, as in 2009 when banks were told to roll over their loans to viable SMEs. Support for small companies has been increased following the 1997 crisis, while the large business groups were forced to restructure. Public support for such intervention is strong, as SMEs are viewed as disadvantaged in competition with the chaebols and deserving of government assistance (KDI et al., 2011).

1. Randall S. Jones is head of the Japan/Korea Desk in the Economics Department of the OECD and Myungkyoo Kim is an economist on that Desk. This paper is based on material prepared for the $O E C D$ Economic Survey of Korea published in June 2014 under the authority of the Economic and Development Review Committee (EDRC). The authors would like to thank Andrew Dean, Robert Ford, Vincent Koen, Virginia Robano, Satoshi Urasawa and Gert Wehinger, as well as officials from the Korean government, for valuable comments on earlier drafts. Special thanks go to Lutécia Daniel for technical assistance and to Nadine Dufour and Mikel Inarrutu for technical preparation.

2. The SME definition varies by sector according to the number of employees as well as capital and sales. The overall share of SMEs in employment falls to $37 \%$ if firms with less than ten employees are excluded. 
4. Small firms' access to credit is limited by their lack of collateral, short credit history and a lack of expertise needed to produce financial statements. From the supply side, the small scale of lending involved may not compensate the cost of screening and monitoring, resulting in an information asymmetry (OECD, 2013b). As a result, financial institutions attribute a high risk of default to borrowers, ${ }^{3}$ providing some justification for government intervention to overcome this market failure. However, such policies can have negative side effects. First, government intervention reduces incentives for financial institutions to improve their capacity for credit evaluation of SMEs, thus impeding the development of a market for SME financing and prompting more government intervention. Second, it allows weak companies to survive thanks to public support. Third, it encourages SMEs to remain small so as to stay eligible for public support, thereby foregoing the efficiency gains and economies of scale associated with growth (OECD, 2014a).

5. After an overview of recent trends in SME financing and government policies to promote it, this paper examines the negative side effects of such support. The fourth section examines the challenges of the venture business sector, the most dynamic category of SMEs and a key to technology-driven growth. The paper then presents the government's policy directions for SMEs as part of its goal of promoting a "creative economy". The final section offers directions for policy, with recommendations summarised in Box 2.

\section{Recent trends in SME financing}

6. In 1997, commercial bank loans to large companies were larger than those to SMEs (Figure 1). However, loans to SMEs increased from $13 \%$ of GDP in 1997 to $42 \%$ by 2009 , before declining somewhat to $36 \%$ in 2012. Meanwhile, loans to large firms, at 12\% of GDP in 2012, remain below their 1997 level despite an upward trend since 2006, reflecting their restructuring to reduce debt following the 1997 crisis. Indeed, the top 30 chaebols' debt-to-equity ratio fell from $500 \%$ at the end of 1997 to $118 \%$ by 2005 . In addition, large firms increased direct financing through capital markets, thereby reducing their reliance on bank loans. In contrast, SMEs have less access to capital markets; direct financing through corporate bonds, paid-in capital increases and initial public offerings (IPOs) amounted to only $0.15 \%$ of bank loans outstanding in 2012, compared to $37.5 \%$ in the case of large firms (OECD, 2012a and Financial Supervisory Service, 2013a). From the perspective of banks, the loss of large corporate customers following the 1997 crisis encouraged lending to small firms.

Figure 1. Commercial bank loans to SMEs and large firms

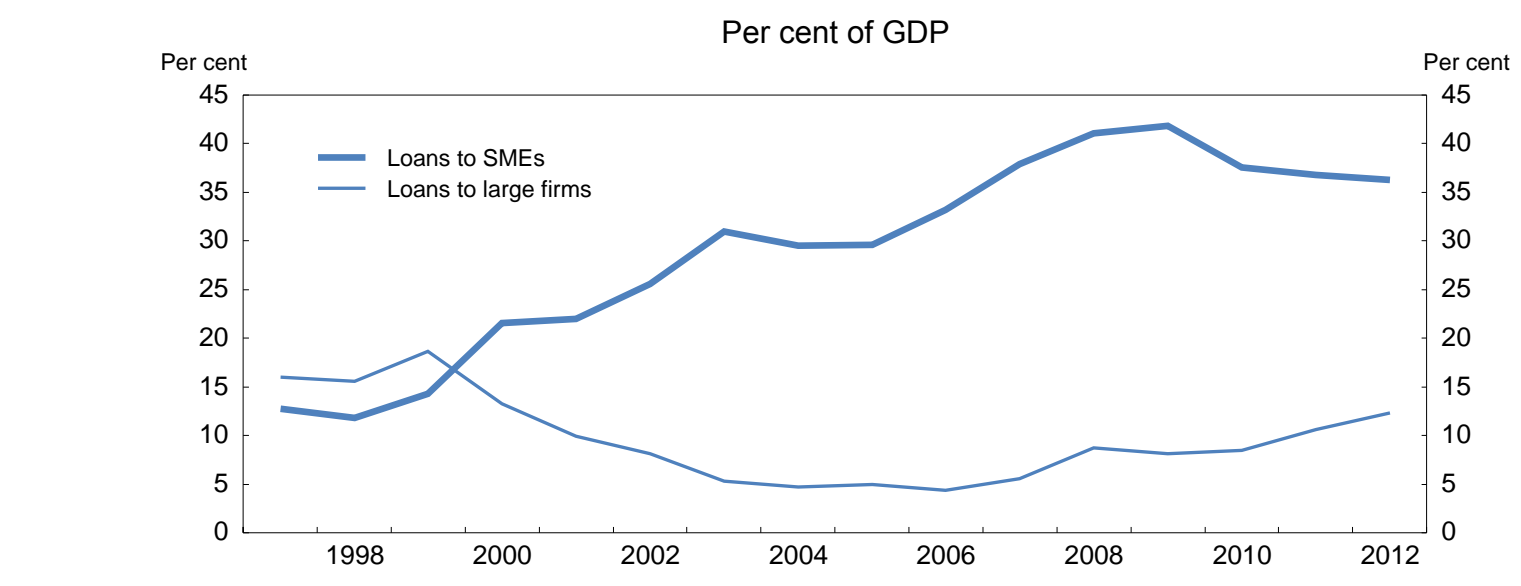

Source: OECD (2013b).

3. The information asymmetry is self-reinforcing. If financial institutions reduce their exposure to SMEs, their information about small companies will decrease, exacerbating the information asymmetry and decreasing the amount of credit supplied to small companies. 
7. In the wake of the global financial crisis, bank lending to SMEs increased only $4 \frac{1}{2}$ per cent (in nominal terms) over 2008-10, although this was much higher than the average decline of $2 \%$ in the 20 OECD countries reporting data (OECD, 2013b). The slowdown in Korea reflected the sharp rise in perceived credit risk, leading to a tightening in domestic banks' lending attitude, according to the Bank of Korea's survey of domestic banks (Figure 2). Nevertheless, lending to SMEs continued to rise due to increased public support, including loan guarantees (see below). Even as the government scaled back public support for SMEs over 2010-12, bank lending to SMEs increased by another $4 \frac{1}{2}$ per cent, thanks in part to an easing in bank lending attitudes. These trends suggest that government SME policy has played a counter-cyclical role. In 2011, banks accounted for $67.8 \%$ of SMEs' financing, compared to $17.2 \%$ for nonbank financial institutions (Table 1).

Figure 2. Banks' lending attitudes towards SMEs, large firms and households
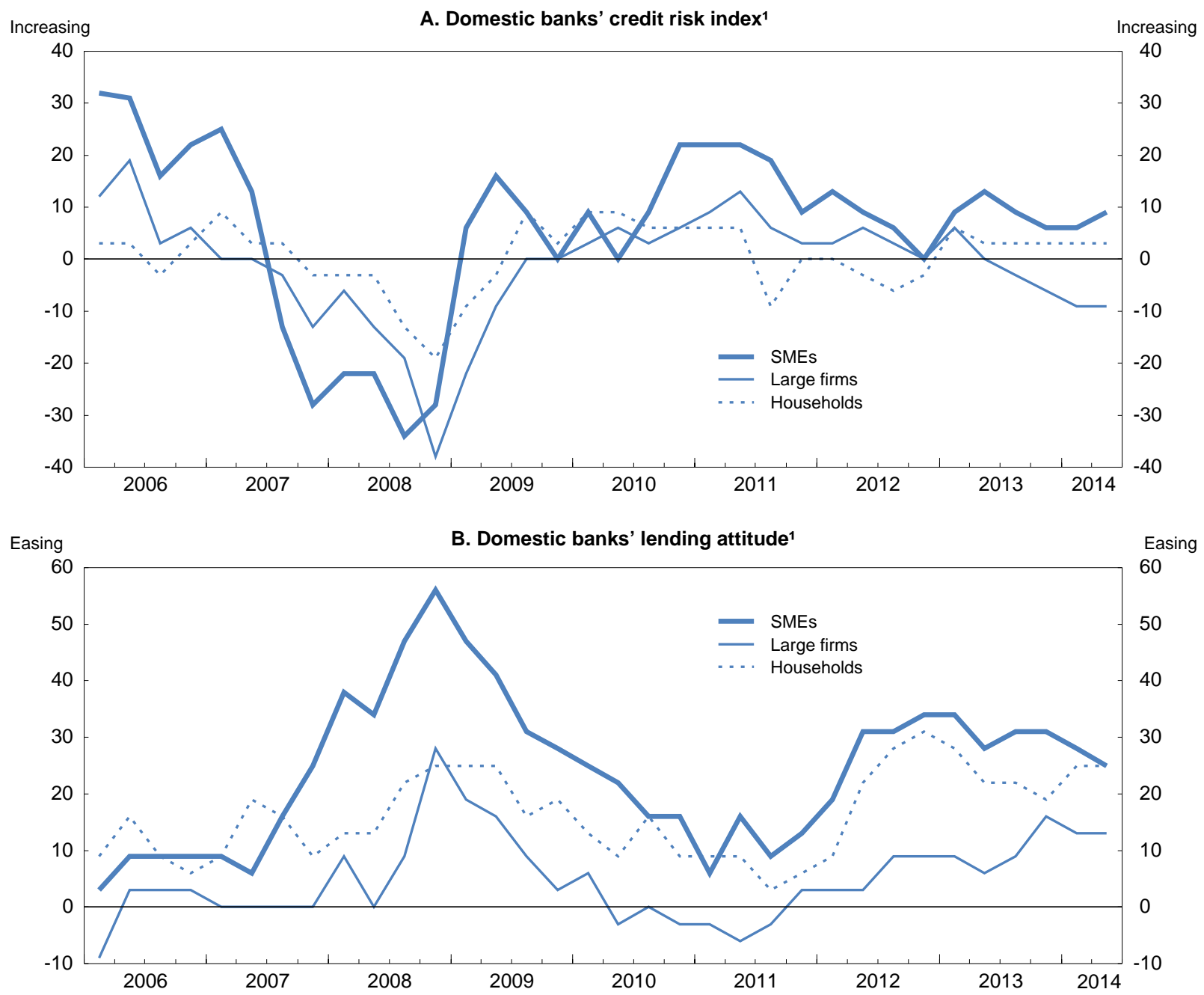

1. The index is calculated as: $1.0^{*}$ [share of banks responding "significant increase (easing)"] +0.5 * [share of banks responding "slight increase (easing)"] - 0.5 * [share of banks responding "slight decrease (tightening)"] - 1.0 * [share of banks responding "significant decrease (tightening)"].

Source: Bank of Korea. 
Table 1. Sources of SME financing

As a per cent of the total ${ }^{1}$

\begin{tabular}{c|l|c|c|c|c|c|c}
\hline Year & Banks & Non-banks & $\begin{array}{c}\text { Bonds and } \\
\text { equities }\end{array}$ & $\begin{array}{c}\text { Venture } \\
\text { investment }\end{array}$ & $\begin{array}{c}\text { Government } \\
\text { guarantees }\end{array}$ & $\begin{array}{c}\text { Other } \\
\text { government }\end{array}$ & Total \\
\hline 2004 & 61.1 & 22.7 & 0.6 & 1.2 & 13.6 & 0.8 & 100.0 \\
2006 & 64.0 & 22.7 & 0.8 & 0.8 & 11.0 & 0.7 & 100.0 \\
2008 & 68.0 & 21.0 & 0.8 & 0.7 & 8.9 & 0.6 & 100.0 \\
2009 & 64.7 & 21.0 & 1.0 & 0.7 & 11.7 & 1.0 & 100.0 \\
2010 & 64.5 & 20.7 & 0.7 & 0.8 & 12.3 & 1.1 & 100.0 \\
2011 & 67.8 & 17.2 & 0.5 & 0.9 & 12.3 & 1.4 & 100.0 \\
\hline
\end{tabular}

1. Government guarantees are assumed to cover bank lending. Some of the lending by government institutions is reported as loans by banks and non-banks.

Source: Sohn and Kim (2013).

\section{Government policies to promote SME financing}

8. Financial institutions are intermediaries that reduce the information asymmetry between potential lenders and borrowers. ${ }^{4}$ However, the cost of overcoming the asymmetry hinders financial transactions and can even prevent them. In the case of SMEs, the costs are especially large, given that the information asymmetry is more severe (OECD, 2006). Compared to mortgage lending, which accounts for half of loans to households, lending to SMEs is more complicated, as information about small companies is difficult and costly to obtain. Moreover, it is less reliable than that for large companies, which is reviewed by external auditors. Consequently, the risk of lending to SMEs is greater compared to larger and more established firms. The extra cost and risk attached to lending to smaller firms encourage banks to focus instead on large firms and mortgage lending, thus reducing the number and size of SME loans and further limiting banks' capability to evaluate SME credit risks. One way of overcoming these obstacles is for financial institutions to demand collateral or credit guarantees by a third party, although this is not feasible for many potential borrowers. As a result, financial resources are not efficiently allocated and market failures occur (Stiglitz and Weiss, 1981 and Berger and Udell, 1990), creating the need for a government role in SME financing.

\section{Direct financial support through the government and public institutions}

9. The government plays a central role in SME financing through a number of channels (Figure 3). The government provides financial support through lending and the provision of credit guarantees. The main sources of public lending are the Korea Finance Corporation (KFC) and the Small and Medium Business Corporation (SMBC), which provides funds to banks and lets them choose which firms to finance. Indirect lending enhances the efficiency of asset allocation by utilising the knowledge and experience of financial institutions (KDI et al., 2011). The KFC, another public institution, follows a more market-oriented approach called "on-lending". The KFC provides $40 \%$ or less of SME loans to banks, which cover the remainder under their own responsibility. Such risk-sharing encourages prudent lending by financial institutions. In addition to the indirect and on-lending schemes, the SMBC and KFC lend directly to SMEs. In total, the two institutions provided credit of 11.8 trillion KRW to SMEs in 2011 (Board of Audit and Inspection, 2012), a figure equivalent to $85 \%$ of the increase in the stock of loans to SMEs that year.

4. It is costly for individuals to make credit evaluations of borrowers and manage loans. Financial institutions reduce this transaction cost through specialisation, which develops their capacity for credit evaluation. In other words, financial institutions provide the public good of project screening, based on their experience and knowledge, which makes them better-placed to assess risks. Borrowers, in part, bear the burden of the additional cost of credit evaluations. 
Figure 3. The framework of SME financing support in Korea

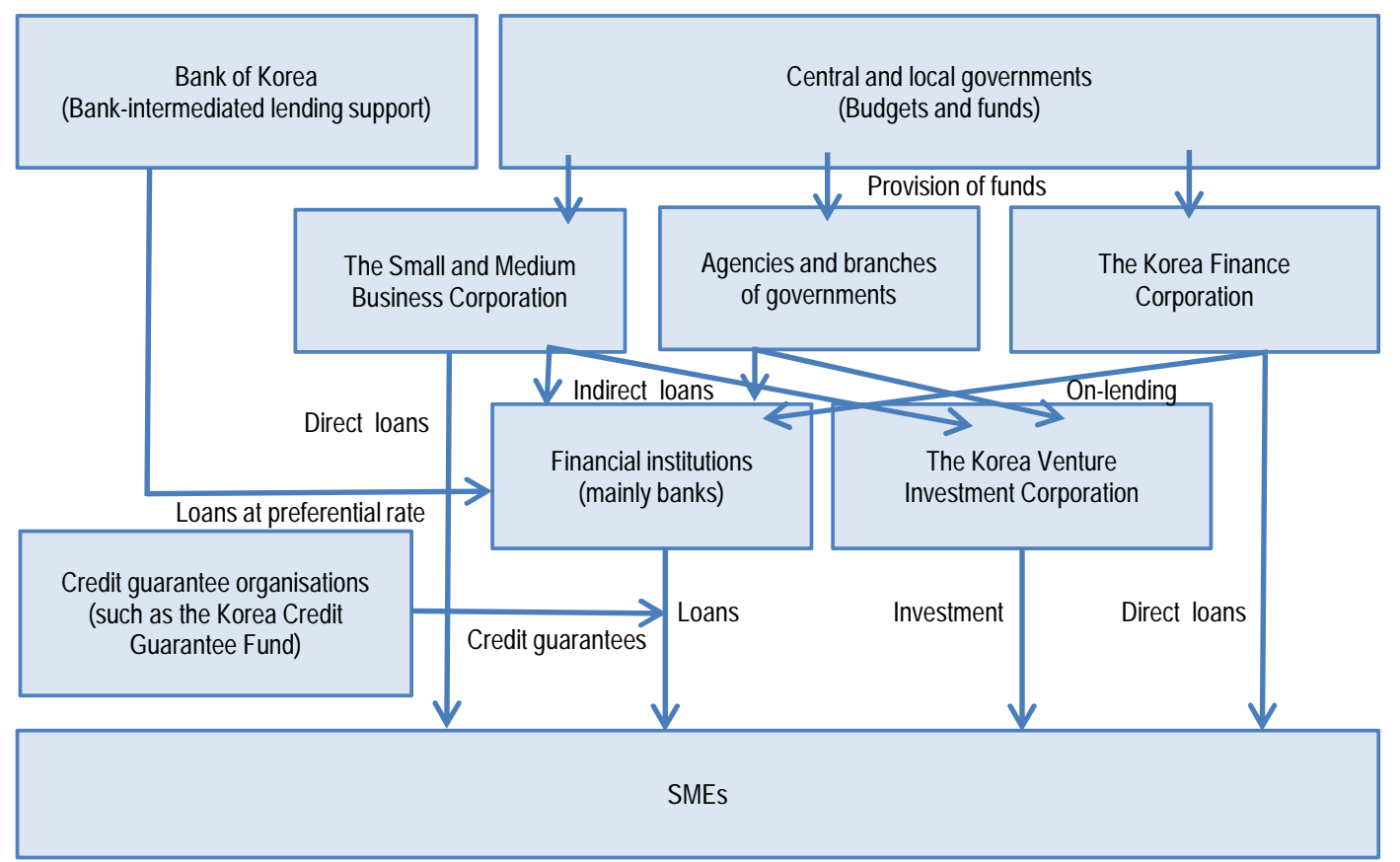

Source: The Board of Audit and Inspection (2012).

10. The government also invests in SMEs through the Korea Venture Investment Corporation (KVIC), which was established in 2004 by the SMBC. The KVIC supports venture businesses through shareholding. It runs the Korea Fund of Funds, which participates in funds created by private venture capitalists. At the end of 2012, this Fund, which is to set to continue until 2035, amounted to 1.5 trillion KRW ( $\$ 1.4$ billion). Shareholding is more advantageous than loans for start-ups and venture businesses facing high uncertainty and lacking a stable cash flow. New firms, which need large funding for R\&D and equipment, tend to prefer risk-sharing with investors rather than paying the interest cost of loans. While debt always has to be paid, dividends are only paid once a firm is profitable. However, equity investments are not as easily monitored as debt and have higher administrative costs. In addition, firms may be reluctant to cede ownership or control rights in exchange for finance. Moreover, the tax system favours debt over equity finance, as interest is deducted before taxes, while equity is paid afterwards (OECD, 2012b). Consequently, as firms mature and achieve a more stable cash flow, the demand for working capital increases and firms tend to prefer loans, as the funding cost is less than for direct financing (Yang et al., 2013).

11. The most important instrument of public support is credit guarantees, which promote bank lending to SMEs by reducing the lenders' exposure to risk. From 2007 to 2011, public support in the form of credit guarantees amounted to 100 trillion KRW (8\% of 2011 GDP) compared to 42 trillion KRW of direct lending (Board of Audit and Inspection, 2012). Credit guarantees have been found to be successful in increasing lending to SMEs in a number of countries. In Korea, guarantees are provided through the Korea Credit Guarantee Fund (KCGF), the Korea Technology Finance Corporation (KOTEC), the SMBC and 16 Local Credit Guarantee Foundations that were established by the government and directly controlled by it. To cope with the 2008 financial crisis, the balance of guarantees increased from 44.9 trillion KRW in 2008 to 70.5 trillion KRW in 2010. In addition, the ceiling on the size of individual credit guarantees was expanded from 3 billion KRW to 10 billion KRW ( $\$ 9.6$ million). Finally, the ceiling on the coverage of credit guarantees was raised from $85 \%$ of the loan amount to $100 \%$. New guarantees by the 
KCGF, KOTEC and the Local Credit Guarantee Foundations rose by 17 trillion KRW in 2011, exceeding the 14 trillion KRW increase in SME loans outstanding that year (Board of Audit and Inspection, 2012).

12. KOTEC, which was established in 1989 to support SMEs possessing new technology, gradually increased its credit guarantees by expanding the definition of SMEs with new technology. By 2005, 53\% of its guarantees were to firms that also had guarantees from the KCGF. To reduce the overlap, the government forced KOTEC and the KCGF to more clearly define their mandates. KOTEC strengthened its focus on SMEs with technology by relying on an outside assessment by a national network of Technology Appraisal Centres. By 2011, the share of KOTEC-guaranteed loans also guaranteed by the KCGF had fallen to $9 \%$, while the share of KCGF-guaranteed loans also guaranteed by KOTEC had fallen from $26 \%$ to $5 \%$, thus reducing the overlap (Board of Audit and Inspection, 2012). KOTEC has been cited as an example of good practice, as it requires both a commercial and technical evaluation of firms that request credit guarantees. Firms whose loans were guaranteed by KOTEC have had a higher survival rate than those guaranteed by the KCGF, suggesting that the technology evaluations play a useful role (Kang and Heshmati, 2008).

\section{Regulatory measures and moral suasion on financial institutions}

13. In addition to financial support with direct loans and credit guarantees, the government promotes SME financing through moral suasion on financial institutions, especially when credit conditions tighten. As noted above, the government asked banks to roll over SME loans automatically to prevent the default of sound SMEs in the wake of the 2008 financial crisis. Moreover, to receive guarantees on their external debt or injections of public capital, banks had to sign a memo of understanding with the government, promising to increase lending to SMEs as a condition. Around 160 trillion KRW of loans were rolled over in 2009, about $90 \%$ of the loans expiring that year (OECD, 2012b). As for credit guarantees, 30.9 trillion KRW were rolled over, benefiting more than 176 thousand firms. In 2009, the government also introduced the Fast Track Programme, which required banks to evaluate SMEs on the base of guidelines set by the Financial Supervisory Service to determine whether they should receive new loans or face restructuring (Financial Services Commission et al., 2008 and Financial Services Commission et al., 2009).

14. The Bank of Korea has also boosted SME lending through its Bank-Intermediated Lending Support Facility, which provides funds to banks at preferential rates subject to certain conditions. Since August 2013, the scheme's base rate has been between $0.5 \%$ and $1.0 \%$ per year, well below the central bank's policy rate of $2.5 \%$. To receive the full amount of funds available under the Facility, nationwide banks must allocate more than $45 \%$ of their new loans to SMEs (more than $60 \%$ in the case of local banks). The Bank of Korea modifies the size of the scheme and the interest rate based on financial and economic conditions. In 2009, for example, the ceiling on lending was raised from 6.5 trillion KRW to 10 trillion $\mathrm{KRW}$, while the interest rate was cut from $3.5 \%$ to $1.25 \%$. Bank participation in the facility is voluntary and depends on the gap between the market rate and that offered by the facility. The relatively low policy interest rate since 2008 has kept the gap with the market rate quite low, thus reducing banks' incentive to participate in the scheme.

\section{Problems related to government's intervention in SME financing}

15. While in general terms, government support for SME financing is justified by market failures, such intervention can have negative side effects. In particular, it causes distortions by limiting the development of market-based SME financing, slowing the restructuring of weak SMEs and discouraging the expansion of smaller firms. Moreover, public financial support does not seem to improve the performance of the firms that receive assistance, while wasting public resources. The challenge is to address market failures while reducing the distortions and waste. 


\section{Generous government support has caused distortions}

\section{The development of market-based SME financing has been impeded}

16. Government intervention in SME financing in Korea is quite large compared to other OECD countries. According to the OECD measure, the share of SME loans guaranteed by the government was $12.2 \%$ in 2011 , well above the average of $4.9 \%$ for 13 OECD member countries (Figure 4 ). The share in Korea increased following the crisis, rising from $10.8 \%$ in 2007 to a peak of $12.7 \%$ in 2010 .

Figure 4. International comparison of government loan guarantees

As a per cent of total loans to SMEs in 2011 or latest year

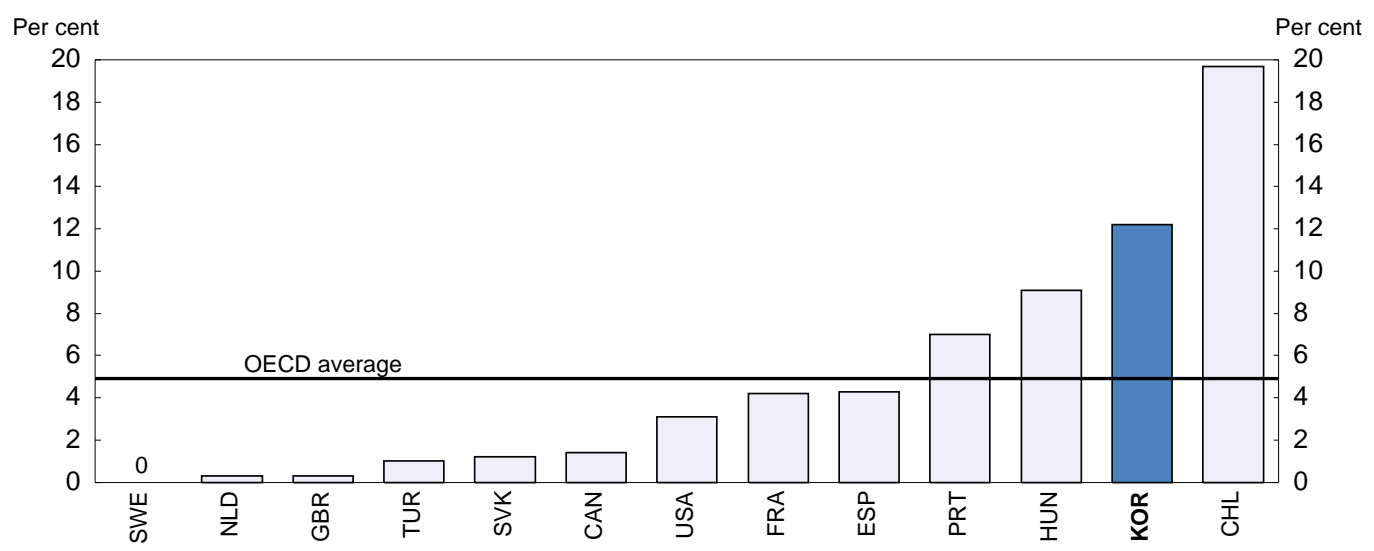

Source: OECD (2013b).

17. The government's large role in SME financing in terms of providing direct credit and guarantees hinders the development of the market (Sohn and Kim, 2013). Financial institutions are content to enjoy stable profits at low risk thanks to government credit guarantees, thus reducing incentives to develop their credit evaluation and risk management skills for SME lending. SMEs also have an incentive to rely on government loans, which are easier to obtain and carry lower interest rates than those offered by financial institutions. Indeed, the interest rate of SMBC loans for SMEs was 3.6\% in late 2013 compared to the market interest rate of $4.8 \%$. Such a gap discourages borrowing from financial institutions, thus slowing the development of a SME financing market.

18. Most lending to smaller firms is still made on the basis of collateral or credit guarantees provided by the government. The share of "pure credit loans" - loans from private financial institutions that are not guaranteed by a public institution or collateralised - was $21 \%$ of lending to SMEs in the manufacturing sector in 2012, although that is a marked increase from the 7\% in 2000 (Figure 5). Surveys of SMEs confirm that the share of pure credit loans has increased. The share of SMEs complaining about excessive requests for collateral and credit guarantees by financial institutions fell from $40 \%$ in 2003 to $20 \%$ in 2012 (Sohn and Kim, 2013). However, the share that responded that interest rates are too high rose from $13 \%$ to $32 \%$.

19. The government has long tried to reduce its intervention in SME financing, recognising that the level of credit guarantees in Korea are higher than in most other countries. In 2005, the government announced plans to reduce the shares of long-term credit guarantees, large guarantees and guarantees given to larger SMEs (Ministry of Finance and Economy, 2005). However, Korea, like most other OECD countries, increased support to SMEs to mitigate the impact of the 2008 crisis (OECD, 2013b). In particular, the plan to reduce the share of long-term credit guarantees was suspended following the crisis (Financial Services Commission et al., 2008 and Financial Services Commission et al., 2009). 
Figure 5. Pure credit loans ${ }^{1}$

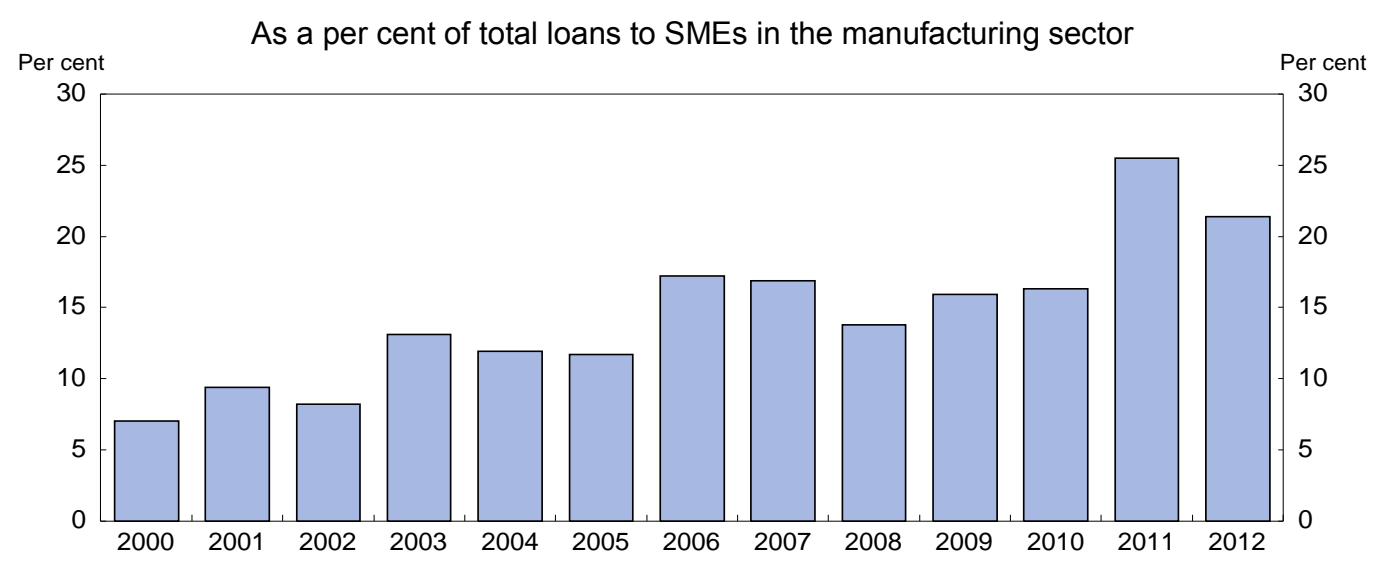

1. Loans from private financial institutions that are not guaranteed nor collateralised by public institutions for SMEs in the manufacturing sector. This information is based on an annual survey by the Korea Federation of Small and Medium Business.

Source: Sohn and Kim (2013).

20. However, even after the recovery from the crisis, the scaling back of public support has been modest, as SMEs have resisted a reduction in government support. Financial institutions and government agencies in charge of SME financing and credit guarantees also have a self-interest in maintaining high levels of support. Consequently, government loan guarantees, which rose from 44.4 trillion KRW (12.0\% of lending to SMEs) in 2007 to 70.5 trillion KRW (16.0\%) in 2010, remained near their peak in 2011, despite the government's goal of reducing guarantees.

\section{Generous government support hinders the restructuring of weak SMEs}

21. Government intervention often supports non-viable SMEs, sometimes referred to as "zombies". Such support delays the restructuring of troubled firms, thus weakening a country's growth potential by limiting viable companies' access to finance (Caballero et al., 2006). Once loans are given to a non-viable firm, financial institutions and credit guarantee providers share a common interest in its survival, as a default would result in losses for both of them. To delay or prevent such a loss, they may continue to support the firm, a phenomenon referred to as "evergreening".

22. SME policies have been criticised for extending the life of non-viable companies in Korea and thereby reducing the country's growth potential (Kim and Koo, 2010). The share of SMEs whose earnings (before interest and taxes) were insufficient to even cover their interest payments - the so-called interestcoverage ratio - rose from $34.3 \%$ in 2007 to $37.0 \%$ at the end of 2012 (Figure 6). Even more problematic is the share of firms that have managed to survive despite an interest-coverage ratio below $100 \%$ for an extended period. A Bank of Korea study of 1381 SMEs with a ratio below $100 \%$ between 2000 and 2002 found that $27.4 \%$ had achieved a ratio of at least $100 \%$ by 2010 while $9.7 \%$ went out of business. Consequently, a majority of the firms $(62.9 \%)$ had somehow survived for a decade while failing to earn enough income to cover their interest payments (Bank of Korea, 2012b). Another study of 1200 listed firms found that $16.6 \%$ of SMEs had an interest-coverage ratio of less than $100 \%$ for three years in a row compared to $8.3 \%$ of large companies (Noh and Lee, 2013).

23. The policies introduced to assist SMEs in the wake of the 2008 crisis appear to have exacerbated the problem of non-viable companies. Despite the slowdown in output growth to $3.7 \%$ in 2011, the number of bankruptcies was only about half of that in 2007 (Figure 7). Korea was one of only four OECD countries in which bankruptcies were lower in 2011 than in 2007 (OECD, 2013b). 
Figure 6. The share of SMEs with an interest-coverage ratio ${ }^{1}$ of less than $100 \%$

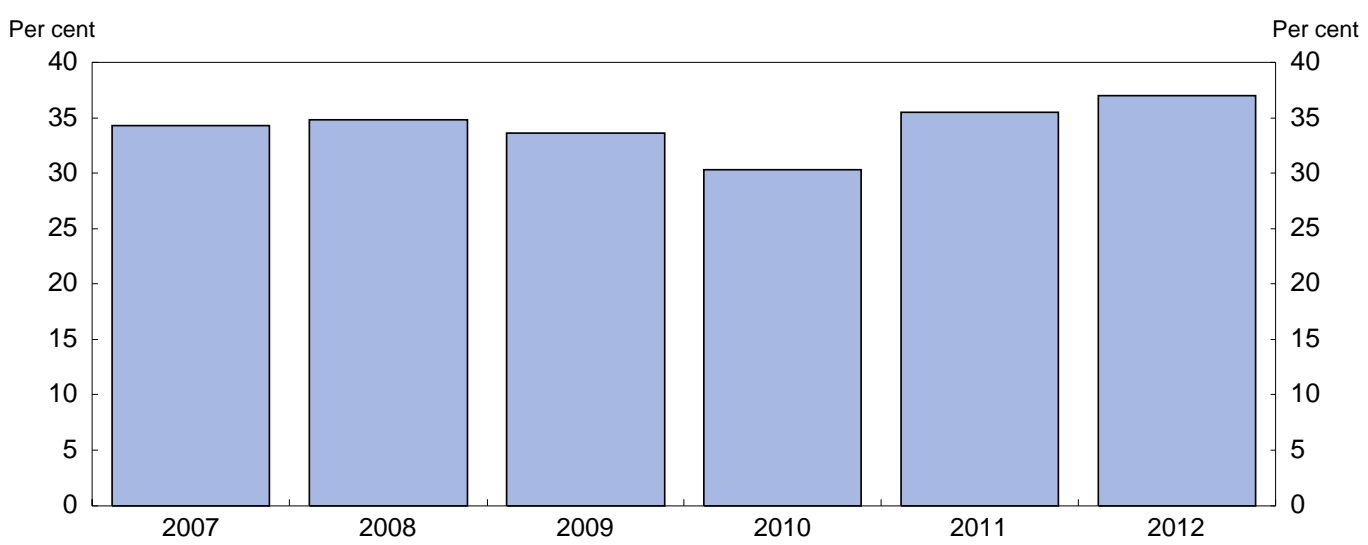

1. Calculated by dividing a company's earnings before interest and taxes (EBIT) by its interest expenses. The firms with a ratio of less than $100 \%$ are unable to pay their interest costs from current earnings.

Source: The Bank of Korea (2012b).

24. The long-term survival of non-viable SMEs is facilitated by government financial support for mature firms. The market-failure rationale for public support to SMEs suggests that support should be targeted at relatively young firms, given that they face greater challenges in receiving market-based financing due to their short business histories and the lack of transactions with financial institutions. However, in Korea, about one-half of the loans and credit guarantees provided by the KCGF and KOTEC in 2010 were to companies that were more than ten years old (Figure 8). In contrast only $20 \%$ of support was for firms created during the past five years. Moreover, the proportion of support from KCGF and KOTEC given to firms with a business history of more than ten years rose between 2006 and 2010. While the SMBC is a bit better in this regard, the average age of firms receiving assistance from each of the three public institutions is around nine years (Table 2).

Figure 7. Korea has experienced a sharp drop in the number of bankruptcies

The number of bankruptcies in 2008 and 2011 compared to 2007 (which equals 100)

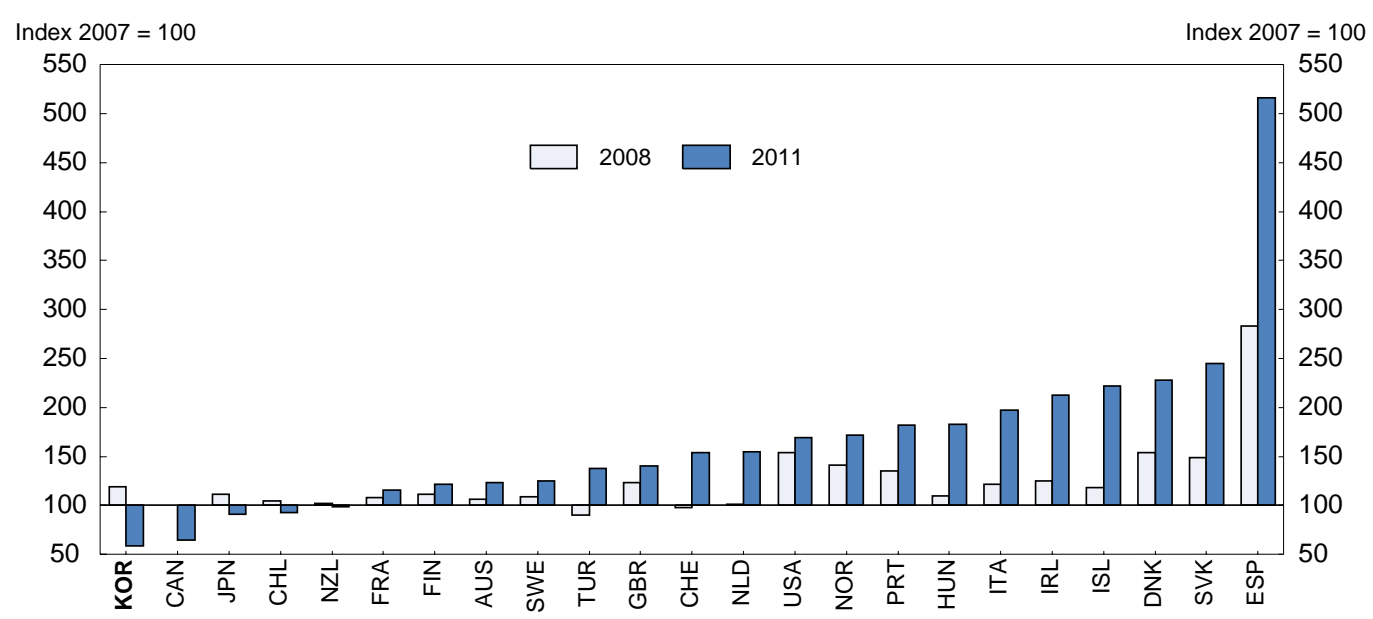

Source: OECD (2013b). 
Figure 8. The share of government financial support ${ }^{1}$ given to SMEs according to the age of the firm

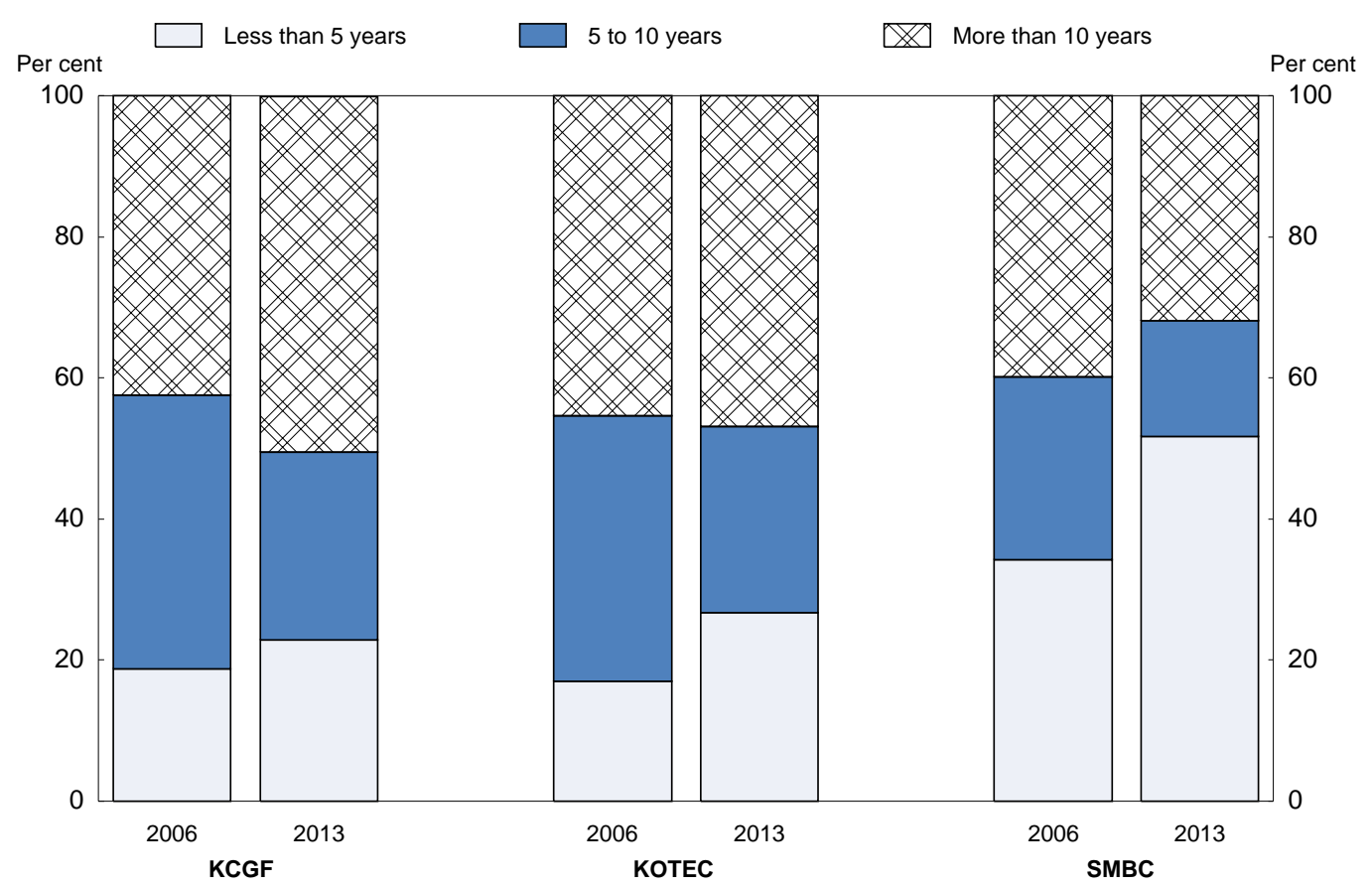

1. Loans and credit guarantees from the KCGF, KOTEC and SMBA.

Source: Hong (2012) and SMBA.

25. In addition, the market-failure rationale for SME support also implies that the length of support should be relatively short. Lending based on public guarantees should create a relationship between the financial institution and the firm that overcomes the information asymmetry and eliminates the need for such guarantees (OECD, 2013b). However, in Korea, a significant share of public support is long term, thereby helping to prop up weak companies. As of 2011, 11\% of the credit guarantees from the KCGF and KOTEC had been given to the same firm for more than ten years (Figure 9). In addition, focusing on young SMEs would tend to limit the size of guarantees. In 2011, 4.5\% of guarantees exceeded 1.5 billion KRW (\$1.4 million), although this has fallen from $10.7 \%$ in 2007 . The long-term nature of SME support and its generosity discourages smaller firms' growth.

Table 2. Firms receiving public financing support and guarantees

For the period 2003 to 2009

\begin{tabular}{l|c|c|c}
\hline Institution providing support & $\begin{array}{c}\text { Average number of } \\
\text { regular employees }\end{array}$ & $\begin{array}{c}\text { Average } \\
\text { age of firm }\end{array}$ & $\begin{array}{c}\text { Per cent in } \\
\text { manufacturing }\end{array}$ \\
\hline SMBC & 43.9 & 9.0 & 87 \\
KOTEC & 32.8 & 9.5 & 73 \\
KCGF & 16.1 & 8.8 & 0 \\
\hline
\end{tabular}

Source: KDI et al. (2011). 
Figure 9. The shares of government guarantees that are long term and large in value ${ }^{1}$

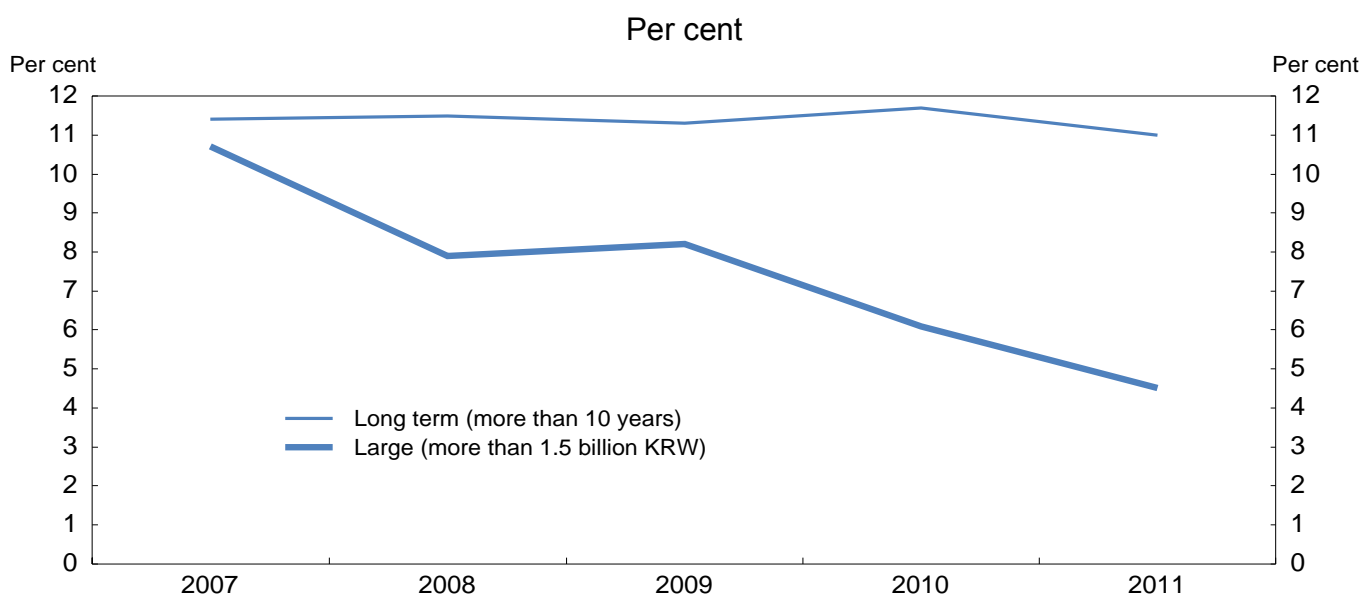

1. Guarantees by KCGF and KOTEC.

Source: The Board of Audit and Inspection (2012).

The long-term nature of SME support and its generosity discourages smaller firms' growth

26. A notable aspect of Korea's corporate landscape is the relatively small number of middle-sized companies. Of the several million SMEs (i.e. firms with less than 300 employees in manufacturing and less in most other sectors) in 2002, only 696 had expanded into mid-sized companies (defined as 300 to 999 workers) by 2012 (Statistics Korea, 2013). The low number of firms that exit the SME category, the socalled "Peter Pan syndrome", reflects the generosity and long duration of government support, as well the abrupt end to such support once companies graduate from the SME category. Indeed, of the more than one thousand SME programmes (see below), only 50 have a time limit (KDI et al., 2011). In addition to these programmes, firms that graduate from SME status lose access to 47 government support measures covering taxes, marketing and employment (OECD, 2014a).

\section{Government financial support for SMEs has little impact on their performance}

27. A recent study by a government research institute compares the performance of firms three years after they began to receive government financial support through one of the four major institutions to those that did not during the period 2003 to 2009 . The study found little difference in the performance of the two groups in terms of profitability and growth (Table 3). All else equal, government support:

- Failed to increase the operating profit ratio, while having a mixed impact on the net profit ratio.

- Reduced sales growth in the case of two of the support programmes.

- Improved the rate of return on assets while deteriorating the return on equity.

- Improved the financial position by reducing the debt-to-equity ratio.

28. By institution, KOTEC stood out for having a positive impact on sales growth, reflecting the importance of technology as a criterion for selecting which firms receive guarantees. The SMBC had the worst performance, as recipient firms had weaker net profits and slower sales growth than firms without guarantees. The results suggest that the choice of recipient firms by public guarantee institutions, with the exception of KOTEC, is not based on their growth potential. 
ECO/WKP(2014)58

Table 3. The impact of public financial support for SMEs on their performance

Percentage-point differences between firms receiving support and those who do not between 2003 and $2009^{1}$

\begin{tabular}{l|c|c|c|c}
\hline Performance indicator & SMBC & KOTEC & KCGF & KFOF \\
\hline Return on assets & -0.02 & $0.778^{* * *}$ & $0.26^{* *}$ & 2.26 \\
\hline Return on equity & $-2.53^{* * *}$ & 0.08 & $-1.71^{* * *}$ & 7.12 \\
\hline Net profit ratio & $-0.43^{\star * *}$ & -0.04 & $0.20^{\star * *}$ & -2.05 \\
\hline Operating profit ratio & -0.10 & -0.02 & 0.028 & -6.16 \\
\hline Growth of sales & $-3.99^{* * *}$ & $3.35^{* * *}$ & $-1.36^{*}$ & 5.25 \\
Growth of operating profit & -6.00 & 2.17 & -1.23 & -120.80 \\
\hline Debt-to-equity ratio & $-42.16^{* * *}$ & $-19.15^{* * *}$ & $-32.26^{* * *}$ & 84.06 \\
\hline Equity-to-capital ratio & $3.54^{* * *}$ & $3.27^{\star * *}$ & $5.26^{* * *}$ & -3.86 \\
\hline
\end{tabular}

1. Based on a difference in differences approach. The asterisks indicate that the percentage differences are significant at the $1 \%$ level $\left({ }^{* * *}\right), 5 \%$ level $\left({ }^{* *}\right)$ or $10 \%$ level $\left({ }^{*}\right)$.

Source: KDI et al. (2011).

29. Another concern is the steady deterioration in the performance of small SMEs - defined as annual sales of less than 10 billion KRW (\$9.6 million). Indeed, the operating income ratio of small SMEs declined to $-4.8 \%$ of total sales in 2011 compared to $+4.7 \%$ for larger SMEs, while their debt-equity ratio has risen to nearly $240 \%$, well above the $140 \%$ for larger SMEs (Figure 10). The share of small SMEs classified as marginal - companies with either a net interest coverage ratio below $100 \%$ or negative operating cash flows during the preceding three years - has been increasing, reaching $34 \%$ at the end of 2011 (Panel C). The share is more than three times higher than that for larger SMEs, which has been stable at around $10 \%$. In addition, $27 \%$ of small SMEs have completely exhausted their capital compared to $10.4 \%$ of larger SMEs that are classified as marginal (Bank of Korea, 2012b).

30. The significant share of SMEs that are classified as marginal or have exhausted their capital creates concerns for the financial sector, although the quality of SME loans appears to have remained sound. The share of substandard and below loans (SBL) - defined as principal or interest payments suspended for more than six months - was 2.2\% at the end of March 2014, down from 3.1\% in 2010 (Figure 11). Meanwhile, the amount of new SBLs to SMEs fell from 24 trillion KRW in 2010 to 14 trillion KRW in 2012 (3\% of the stock of loans to SMEs), which was more than offset by the write-off of distressed loans that year. In addition, banks are well capitalised. Nevertheless, the signs of weakness in the SME sector are troublesome, given that banks have low profits. 
Figure 10. The performance of small SMEs ${ }^{1}$ is deteriorating
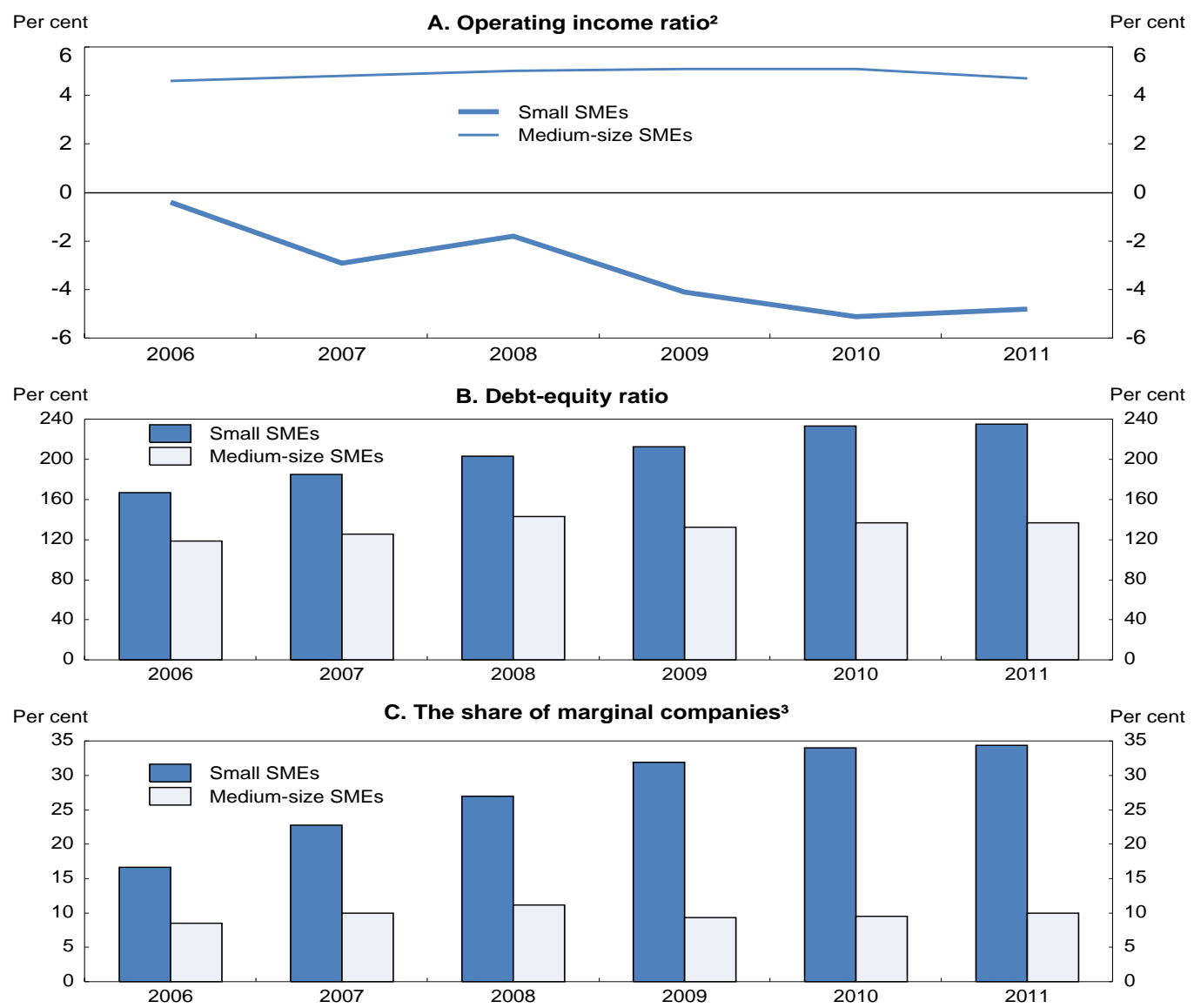

1. Firms with annual sales of less than 10 billion KRW (\$9.6 million).

2. Operating income as a share of total sales.

3. Firms with either a net interest-coverage ratio below $100 \%$ or negative operating cash flows during the preceding three years. Source: BOK (2012b).

Figure 11. Substandard and below bank loans ${ }^{1}$ to SMEs In trillion KRW and as a per cent of lending to SMEs

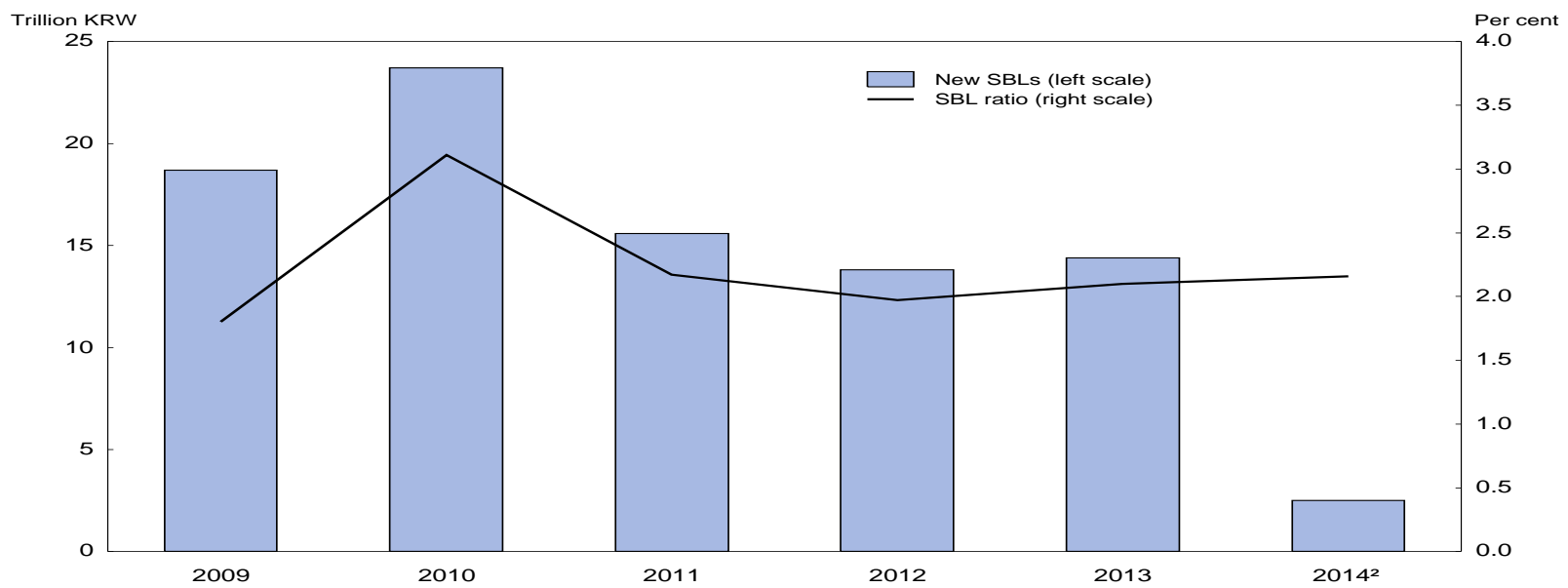

1. Loans on which principle or interest payments have being suspended for more than six months.

2. As of the end of June 2013. At an annual rate, SBLs in 2013 would be 15 trillion KRW, thus exceeding the 2012 figure. Source: Financial Supervisory Service (2014). 


\section{The framework for public support for SMEs is inefficient}

31. The government is implementing a vast array of SME support measures, resulting in significant duplication and a waste of resources. According to the SMBA, 14 central government ministries ran 201 programmes in 2013, while the 16 provincial governments and 130 SME-related organisations administered another 1101 programmes. In the central government programmes, 55.3\% of total outlays were for SME financing, while innovation was the second most important area (Table 4). Even after taking account of the diversity of SMEs, the number of programmes is excessive, resulting in significant duplication and a waste of resources. For example, more than half of the SMEs that received financial support from the SMBC in 2012 also benefited from financial support from other public agencies (Yoon, 2012). ${ }^{5}$ The proliferation of programmes over time has created a complex and confusing landscape for start-ups and SMEs (OECD, 2014a).

32. The large number of SME programmes reflects weak linkages between the 14 central government ministries and the absence of a central authority to co-ordinate programmes run by different institutions and provide an effective ex post review of their performance. Consequently, the level of SME support is determined incrementally by individual ministries, without appropriate direction, resulting in duplication and overlap. Moreover, the lack of an information system that manages all information related to SME programmes results in a mismatch between the supply and demand for SME support. For example, firms at an early stage of growth report a need for assistance with marketing and exports, while government programmes emphasise innovation (KDI et al., 2011).

Table 4. Central government programmes to support SMEs

In billion KRW in 2011

\begin{tabular}{l|c|c|c}
\hline & Outlays & Per cent of total & Number of programmes \\
\hline SME financing & 5387 & 55.3 & 39 \\
Innovation & 1662 & 17.1 & 43 \\
Human resources & 576 & 5.9 & 21 \\
Co-operation with large companies & 291 & 3.0 & 8 \\
Establishing new firms and ventures & 244 & 2.5 & 10 \\
Marketing and exports & 154 & 1.6 & 27 \\
Other & 1433 & 14.7 & 53 \\
\hline Total & 9746 & 100.0 & 201 \\
\hline
\end{tabular}

Source: KDI et al. (2011).

33. Another source of waste in government support is the large and increasing share of credit guarantees from public institutions for SMEs with good credit ratings, which could probably obtain financing without public assistance. The share of KCGF guarantees to SMEs with a rating of B3 and above $^{6}$ increased from 15\% in 2005 to 37\% in 2011 (Yang et al., 2013). In addition, 87\% of loans and guarantees from the four major public institutions (KCGF, KOTEC, KFC and SMBC) were for working capital (Yoon, 2012). Such loans tend to have a short maturity, which matches private financial institutions' preference for short-term lending so as to reduce credit risk. Public institutions should instead provide guarantees that can finance longer-term investments, such as in R\&D.

5. One company received 380 million KRW (\$366 thousand) in 2010, around one-half of its annual sales, from four programmes run by three different ministries (KDI et al., 2011).

6. The KCGF credit rating system divides SMEs into six groups, S, A, B, C, D and E, with C defined as "normal" and B is defined as "good". Within the B category, there are four grades from B4 to B1. 
ECO/WKP(2014)58

\section{The venture capital market is at an early stage of development}

34. As noted above, SME financing is generally provided through lending rather than from financial markets by issuing bonds and equities. In 2011, bonds and equities amounted to only $0.5 \%$ of total SME financing, about the same as in 2004 (Table 1). Financing through bonds and equities requires that third parties, such as investment banks and external auditors, provide credible evaluations of a company to assure investors that it is viable. However, it is difficult for third parties to acquire reliable financial and non-financial information on SMEs. In addition, if the shares or bonds are listed on an exchange, the firm must regularly disclose detailed information, thus increasing the cost of such financing.

35. While these factors explain why most SMEs rely on bank lending, equity financing is critical for start-ups, as they have even less access to loans given their lack of credit records, business relationships with financial institutions and tangible collateral. The success of the new government's strategy to promote a creative economy (see below) depends to a large extent on increasing the rate of business creation and the role of fast-growing young and small firms. Firms that drive one technological wave often fail to participate in subsequent waves. Instead, young firms often have a comparative advantage in commercialising radical innovations. Firms less than five years old, regardless of their size, accounted for less than a fifth of total non-financial business employment but generated half of all new jobs over 2001-11 (OECD, 2013c).

36. One reason for the small role of equity financing in Korea is the weakness of the venture capital market since the collapse of the ICT bubble in the early 2000s. Venture investors, who are willing to accept high risk for high returns, play a crucial role in financing start-ups, including those with new technology and business models. The government jump-started the venture capital market in 1998 through a direct infusion of equity capital from the public sector, generous tax incentives and equity guarantees. Such support was aimed at venture businesses that were identified by a certification system introduced in 1997. The government's objective in developing a venture capital market was part of a strategy to accelerate business restructuring and shift the economy from chaebols to start-ups in knowledge-based industries, foreshadowing the strategy of the current government.

37. However, these policies fuelled a bubble in the Korea Securities Dealers Automated Quotation (KOSDAQ), the secondary stock market that was established in 1996. With the collapse of the ICT bubble, the KOSDAQ, in which about one-half of the listed firms were financed by venture capital, experienced a $90 \%$ decline. The venture capital market contracted by a quarter over 2002-06.

38. However, Korea's venture capital market has rebound steadily since 2006, with paid-in capital more than doubling by 2013 despite the 2008 crisis (Figure 12). The total number of firms with venture investment on their balance sheets has been on an upward trend since 2009, although it remains below its level in the early 2000s. The number of firms classified as venture businesses by the government increased more than threefold from around 9 thousand in 2000 to nearly 29 thousand in 2012. In contrast to some countries, a Korean firm that does not receive investment from a venture capitalist can still be designated as a venture business by spending more than $5 \%$ of sales on $R \& D$ or having its technology certified by the government.

39. Despite the downward trend, venture capital investment was relatively high in Korea at almost $0.1 \%$ of GDP (on a flow basis) in 2012, the third highest among countries for which data are available, although far behind Israel and the United States (Figure 13). The 2008 crisis severely affected venture capital activity in Korea, but recovery has been relatively quick, reaching $92 \%$ of its 2007 level by 2012 . In contrast, in most OECD countries, the level of venture capital investment was less than $60 \%$ of that in 2007. However, despite its relatively large size and strong rebound since the crisis, the venture capital sector in Korea has a number of weaknesses: $i$ ) the number of business angels has fallen sharply; ii) the 
market is dominated by government funds; iii) a relatively small share of venture capital investment occurs at an early stage of firms' life, when it is most critical; iv) the demand side of the venture capital market the proposals made to potential investors - is weak; v) successful entrepreneurs are discouraged from reinvesting their earnings in new ventures; and vi) cultural and institutional factors make it difficult for entrepreneurs to have a second chance after a failure.

Figure 12. Korea's venture capital market has rebounded in recent years

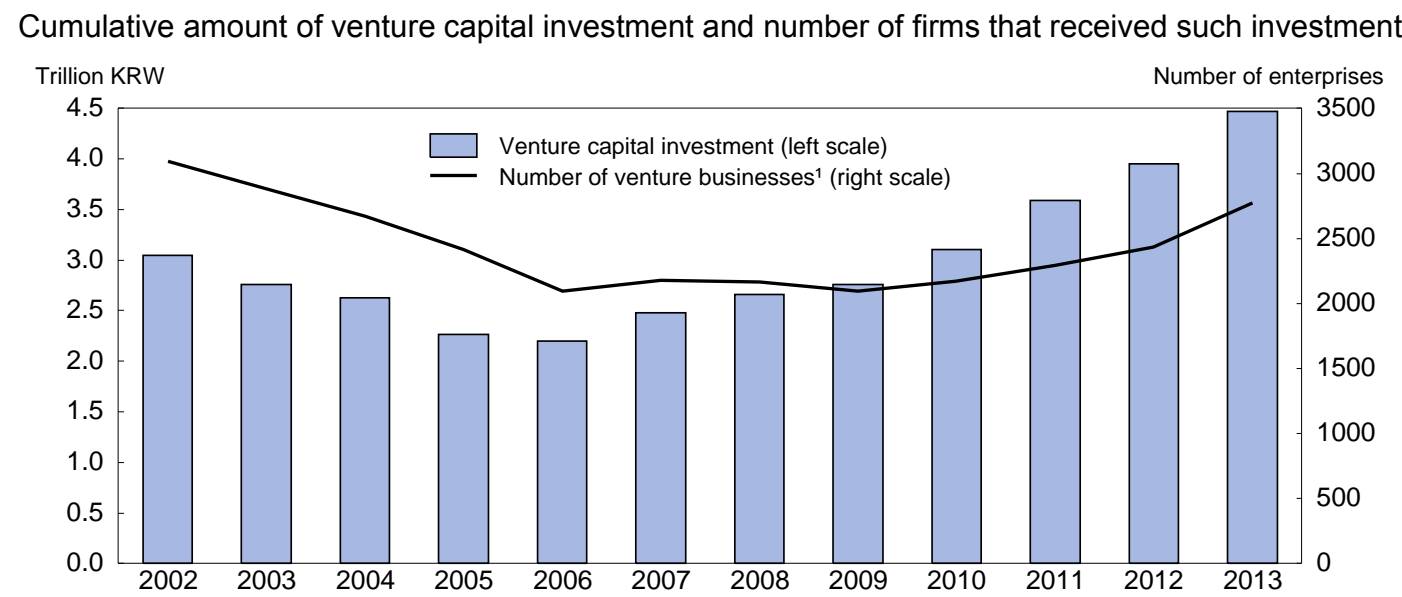

Source: SMBA and Korean Venture Capital Association (2013).

Figure 13. International comparison of venture capital investment Venture capital investment in $\mathbf{2 0 1 2}$ or latest year available

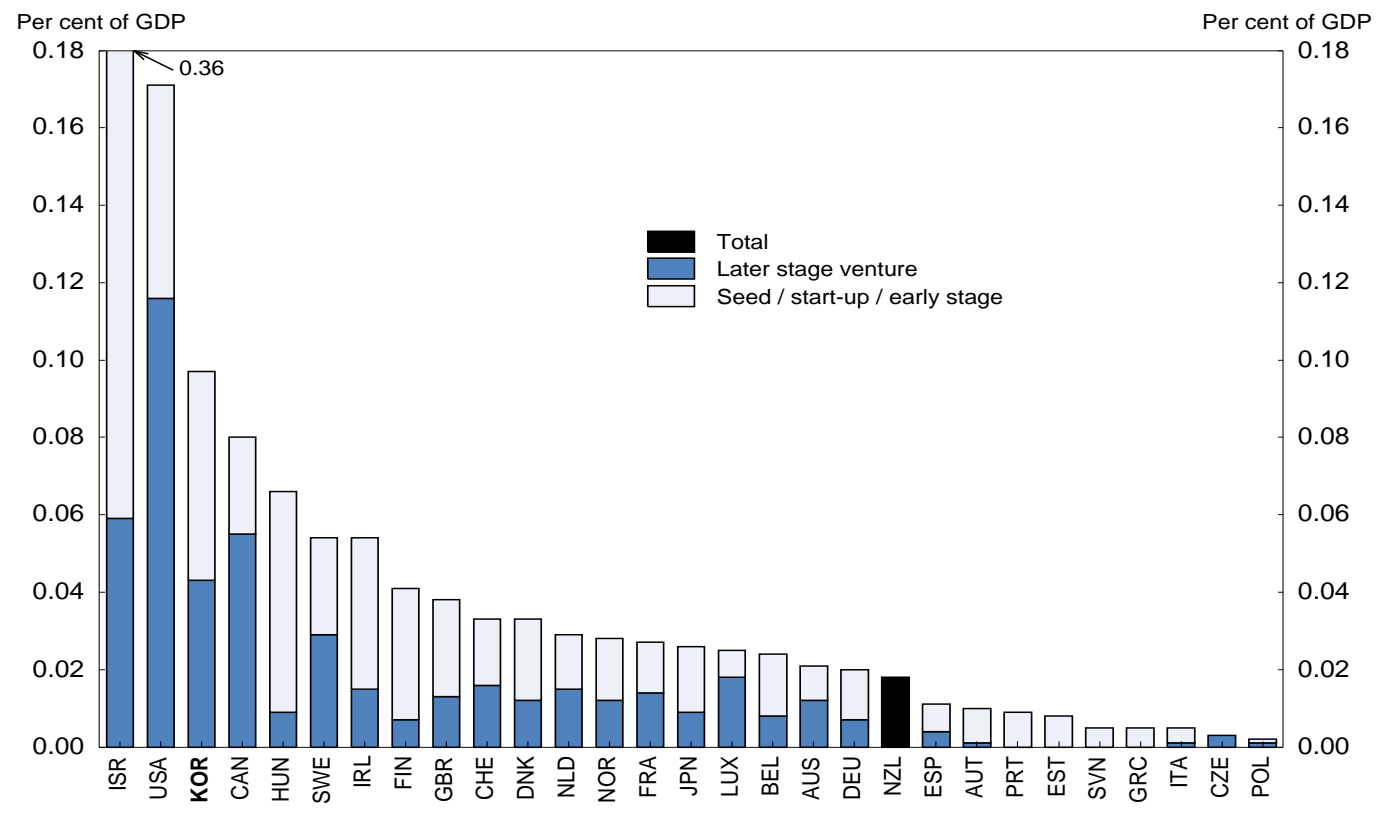

Source: OECD (2013a).

40. First, the number of business angels, who play a crucial role at an early stage of start-ups, has plummeted from nearly 29 thousand before the collapse of the ITC bubble to only 619 before rebounding to 4870 in 2013. This is an impediment to a vibrant venture business sector, as the angels play an important role in mentoring start-ups and providing networking, in addition to their financing role. 
41. Second, as in the case of SMEs, the venture capital market depends heavily on the government. Public funds accounted for $33 \%$ of venture funds in 2012, with an additional $12 \%$ share for public pension funds (MOSF et al., 2013). The large government share risks crowding out private investors.

42. Third, venture capital funds tend to invest in relatively mature companies rather than in firms at an earlier stage when such funding is most critical. Indeed, $55 \%$ of firms receiving venture capital investment in 2012 were older than three years and $27 \%$ were more than seven years old. Moreover, the share of investment by venture capital funds in firms less than three years old fell from $40 \%$ in 2008 to $28 \%$ in 2012 , reflecting institutional weaknesses. In particular, the domestic M\&A market is very underdeveloped compared to other OECD countries (OECD, 2014a). The share of venture capitalists' earnings that are realised from M\&As was only 7\% in 2011 compared to $69 \%$ in the United States. ${ }^{7}$ Cultural factors may also play a role. M\&A activity in Korea historically meant the restructuring of a firm and was associated with bankruptcy proceedings. Moreover, CEOs generally want to remain with the enterprise that they have created, making them reluctant to participate in M\&As. In addition, limits on diversification by the chaebols may discourage M\&A activity.

43. Instead, the primary method for venture capitalists to realise returns from their investment is an IPO in the KOSDAQ, although this is not easy for start-ups due to demanding requirements, including maintaining a high profitability rate. Indeed, the average net profit ratio of newly-listed companies in KOSDAQ ranged from $11 \%$ to $16 \%$ over $2008-12$, making it two to three times higher than the $5 \%$ average of all listed companies (MOSF et al., 2013). Moreover, IPOs take a long time. On average, it takes more than 14 years for start-ups to be listed on KOSDAQ, far exceeding the lifespan of most venture capital funds. Indeed, only 78 of 393 funds in 2010 were more than six years old (Yang et al., 2013). As a result, venture capital funds tend to invest in relatively mature companies. In sum, the major concern about the venture capital market is that too few firms receive early-stage finance.

44. Fourth, while the government has emphasised support to the supply side of the venture capital market, demand-side conditions appear to be the key constraint. A number of OECD countries are shifting the orientation of policy towards measures to strengthen the demand side by enhancing the quality of the business proposals that entrepreneurs present to potential private-sector funding sources (OECD, 2014a). Such an approach recognises that the development of the venture capital industry has followed, rather than preceded, the availability of attractive opportunities. The Korea Venture Capital Association has stated that it is becoming increasingly hard to find good investment opportunities in Korea, leading some of its members to establish operations overseas, particularly in China and Vietnam (OECD, 2014a). In addition, there are complaints that in Korea the most talented individuals work at chaebols rather than becoming entrepreneurs.

45. Fifth, re-investment by venture entrepreneurs who have already achieved success is relatively small for a number of reasons, including the tax system and financial market practices. For example, when shares are sold at more than $30 \%$ above the market price, the sale is subject to the maximum gift tax of $50 \%$ instead of the $11 \%$ capital gains tax. Such high tax rates limit the scope for re-investing gains in the venture capital market.

46. Sixth, the social stigma attached to failure limits the opportunity for entrepreneurs to try again. In addition, the practice of "joint liability" has reduced second chances by requiring a company (the principal borrower) requesting loans from financial institutions to obtain a written agreement from a co-guarantor to assume the debt in the case of default. The co-guarantor thus assumed the same obligation as the principal borrower to repay debts. While the company was exempted from the debt obligation after declaring

7. This compares earnings from M\&As as a share of earnings from IPOs and M\&As combined (Korea Venture Capital Association, 2013b). 
bankruptcy, the liability of the co-guarantor was not. In the case of SMEs, most co-guarantors were the owner of the company, relatives or friends. As a result of the practice of joint liability, many CEOs became personally delinquent and were subsequently excluded from the financial market, making it difficult to recover from failure and start again. In addition, joint liability can create chains of defaults.

\section{The government's plan for a "creative economy" by strengthening the role of ventures and SMEs}

47. A top priority of the new administration inaugurated in 2013 is to develop a "creative economy", based on the judgement that Korea has "reached the limits of its "catch-up type strategy', which had driven economic growth for the last 40 years" (MOSF, 2013). The government is now aiming to transform the economic paradigm to one based on Korean creativity. In order to accomplish this vision, the government announced an action plan in June 2013 that aims to: $i$ ) create new jobs and markets through creativity and innovation; ii) strengthen Korea's global leadership through a creative economy; and iii) create a society where creativity is respected and manifested (Box 1). The action plan was supplemented by the "Threeyear Plan for Economic Innovation" that was announced by the President on 25 February 2014 (2014 OECD Economic Survey of Korea).

48. Strengthening SMEs and promoting start-ups and venture businesses are core strategies to accomplish these goals. The May 2013 "Measures to develop a virtuous cycle in the venture start-up capital ecosystem" (Figure 14) aim to address three major obstacles that hinder the development of a sound venture start-up capital ecosystem:

- Promoting angel investment and introducing crowd-funding;

- Developing the market for M\&As involving venture businesses and business angels; and

- Creating an environment that encourages reinvestment by both successful and failed entrepreneurs.

Figure 14. The May 2013 "Measures to improve the venture start-up ecosystem"

\begin{tabular}{|c|c|c|c|c|}
\hline & \multirow[b]{2}{*}{ 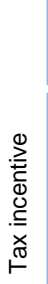 } & $\begin{array}{l}\text { Start-up stage } \\
(0-3 \text { years })\end{array}$ & $\begin{array}{l}\text { Development stage } \\
\text { (4 - } 9 \text { years) }\end{array}$ & $\begin{array}{l}\text { Mature stage (collecting } \\
\text { returns) }(10-15 \text { years) }\end{array}$ \\
\hline \multirow{3}{*}{ 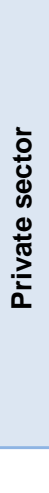 } & & $\begin{array}{l}\text { Promoting angel investment } \\
\text { - Tax deduction ( } 50 \% \text { rate up to } \\
50 \text { million KRW) }\end{array}$ & $\begin{array}{l}\text { Promoting M\&As } \\
\text { - Reducing corporate taxes on } \\
\text { buyers } \\
\text { - Removing gift taxes on those } \\
\text { selling shares to unrelated } \\
\text { shareholders }\end{array}$ & $\begin{array}{l}\text { Promoting reinvestment } \\
\text { - Deferring capital gains taxes on } \\
\text { reinvestment resources }\end{array}$ \\
\hline & 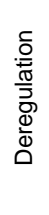 & $\begin{array}{l}\text { Introducing crowd funding } \\
\text { - Allowing on-line funding } \\
\text { platforms and alleviating the } \\
\text { burden of disclosure }\end{array}$ & $\begin{array}{l}\text { Simplifying the process of } \\
\text { M\&A of venture company } \\
\text { - Postponing the designating of the } \\
\text { acquired company as a subsidiary } \\
\text { for } 3 \text { years } \\
\text { - Enlarging exception for the } \\
\text { approval from the general meeting }\end{array}$ & $\begin{array}{l}\text { Strengthening the exchange } \\
\text { for venture and start-ups } \\
\text { - Enhancing the independence of } \\
\text { KOSDAQ } \\
\text { - Establishing the KONEX as an } \\
\text { exchange for SMEs only }\end{array}$ \\
\hline & & N & \multicolumn{2}{|l|}{ Mentoring, consulting, reinvestment } \\
\hline 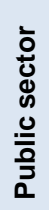 & 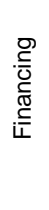 & \multicolumn{3}{|c|}{$\begin{array}{l}\text { Future Creating Fund ( } 0.5 \text { trillion KRW)/Growth Ladder Fund ( } 2.0 \text { trillion KRW)/Credit guarantee }(0.45 \\
\text { trillion KRW) and so on } \\
\text { - Investment in venture companies and start-ups } \\
\text { - Allocate resources for facilitating M\&As, protecting intellectual rights and restart business after failures } \\
\text { Credit guarantees } \\
\text { - M\&As } \\
\text { - Special guarantees for entrepreneurs preparing to launch an enterprise }\end{array}$} \\
\hline
\end{tabular}


ECO/WKP(2014)58

\section{Box 1. The "Creative Economy Action Plan"}

The blueprint adopted by the Cabinet in June 2013 set three goals, six strategies and related tasks.

Goal 1: Create new jobs and markets through creativity and innovation.

Goal 2: Strengthen Korea's global leadership through a creative economy.

Goal 3: Create a society where creativity is respected and manifested.

The six strategies with their related tasks are:

1) Properly compensate for creativity and create an ecosystem that promotes the creation of startups:

- Create the conditions to easily start new businesses through investment, rather than bank financing.

- Patent creative ideas.

2) Strengthen the role of venture businesses and SMEs in the creative economy and their ability to enter global markets:

- The government and public institutions will become the largest customer to support the pioneering of new markets.

- Ease regulations and increase government support to stimulate investment.

- Achieve the goal of growth for startups by accessing global markets.

- $\quad$ Create an ecosystem that encourages co-operation and win-win relations between SMEs and large corporations.

- Construct a system that connects demand, education and recruitment to resolve human resources shortages.

3) Create growth engines to pioneer new markets and new industries:

- Combine science, technology and ICT to energise existing industries.

- Develop new industries based on software and the Internet.

- Create new markets through human-oriented technology innovation.

- Pioneer new markets by discovering and fostering new promising industries for the future.

- Promote market creation and industry convergence through rationalisation of regulation.

4) Foster global creative talent that has the spirit to rise to challenges and pursue dreams:

- Strengthen the development of creative convergence talent.

- Invigorate a challenging entrepreneurial spirit.

- Stimulate the overseas advancement and domestic inflow of creative talent.

5) Strengthen the innovation capacity of science, technology and ICT, which form the foundation for the creative economy:

- Create an autonomous and challenging research environment and support the commercialisation of research outcomes.

- $\quad$ Pioneer next-generation markets by strengthening ICT innovation capacity.

- Stimulate regional economies and strengthen the commercialisation function and regional innovation of universities.

- Solve international social problems through Korean science, technology and ICT in order to raise Korea's status.

6) Promote a creative economic culture together with the Korean people:

- Develop a creative culture that realises creativity and imagination.

- $\quad$ Fuse Korean ideas with public resources through government 3.0.

- Innovate government working methods in order to realise a creative economy.

- Centre the creative economy on the private sector, not the government.

Source: Ministry of Strategy and Finance (2013). 


\section{Establishing a virtuous cycle of growth in the venture business and start-up sector}

49. First, the government intends to promote a shift from loans to investment-oriented financing for ventures and start-ups, reflecting the critical importance of risk-sharing between entrepreneurs and financial institutions during the first three years of a firm's existence.

- Tax incentives for angel investors will be strengthened. For example, the amount of investment in venture businesses that they can deduct from their aggregate income in calculating personal income tax will be raised from $30 \%$ to $50 \%$ of that investment.

- The government established the so-called "Future Creation Fund", totalling 500 billion KRW ( $\$ 471$ million) with the private sector (which provides two-thirds of the Fund) to finance ventures and start-ups (Table 5). Of the total, 200 billion KRW is reserved for investment in start-ups and firms less than three years old. To encourage private-sector investors, they will receive a certain share of the profits upfront before dividing the rest with the government. In the case of a loss, the government will bear up to 20 billion KRW alone before private investors suffer any loss. This Fund is part of the Fund-of-Funds run by the KVIC.

- Entrepreneurs planning to establish a new firm can confirm in advance whether they are eligible for KOTEC's special credit guarantees. The ceiling is 500 million KRW ( $\$ 481$ thousand) per company and the coverage ratio is $100 \%$.

- Crowd-funding via on-line platforms will be introduced to allow start-ups to receive financing. Crowd-funding is defined as the collective effort of many individuals who network and pool their resources, usually through social networking via the Internet, to invest in new projects.

Table 5. New programmes to promote a creative economy

\begin{tabular}{|c|c|c|c|}
\hline Programme & Objective & $\begin{array}{l}\text { Funding } \\
\text { (KRW) }\end{array}$ & $\begin{array}{l}\text { Organisation } \\
\text { responsible }\end{array}$ \\
\hline Future Creation Fund & Promoting investment-oriented & 500 billion $^{1}$ & KVIC \\
\hline $\begin{array}{l}\text { Special Credit Guarantee for Entrepreneurs } \\
\text { Fund for M\&As }\end{array}$ & $\begin{array}{l}\text { For setting up a firm } \\
\text { To promote M\&As }\end{array}$ & $\begin{array}{l}50 \text { billion }^{2} \\
200 \text { billion }\end{array}$ & $\begin{array}{c}\text { KOTEC } \\
\text { Growth Ladder } \\
\text { Fund }^{3}\end{array}$ \\
\hline Credit guarantees for M\&As between SMEs & To promote M\&As & 100 billion & KCGF \\
\hline Fund for Next Venture Generation & $\begin{array}{l}\text { Facilitating re-investment by } \\
\text { successful venture entrepreneurs }\end{array}$ & 100 billion & KVIC \\
\hline Intellectual Property Rights Fund & $\begin{array}{l}\text { To buy patents and technology } \\
\text { from SMEs }\end{array}$ & 200 billion & $\begin{array}{l}\text { Growth Ladder } \\
\text { Fund }^{3}\end{array}$ \\
\hline Restart Support Fund & $\begin{array}{l}\text { To give a second chance to } \\
\text { failed entrepreneurs }\end{array}$ & 100 billion $^{4}$ & $\begin{array}{l}\text { Growth Ladder } \\
\text { Fund }^{3}\end{array}$ \\
\hline
\end{tabular}

1. The private sector provides 350 billion KRW. Of the total, 200 billion KRW is reserved for firms less than three years old.

2. Up to 500 million KRW per entrepreneur.

3. The KDB and IBK put money into this Fund along with private financial institutions.

4. The Fund is to increase from 40 billion KRW in 2013 to 100 billion KRW in 2017.

Source: OECD Secretariat.

50. Second, the government is trying to facilitate M\&As involving ventures and start-ups, thereby meeting investors' demands for early withdrawal from their investment. Buyers can receive a corporate income tax deduction of $10 \%$ of the value of the technology in the merged company. ${ }^{8}$ For sellers, the $11 \%$

8. The value of technology is evaluated by a third party (a technology evaluation organisation defined in the law) or by a formula (the value of the merged company - the market price of shares * 1.3). 
capital gain tax will be applied instead of the gift tax, whose rate goes up to $50 \%$. Regulations related to M\&As are also being liberalised; i) when large companies buy shares in a SME or venture business, the designation of the smaller firm as a subsidiary can be postponed for three years, thus avoiding the regulations imposed on chaebol affiliates; and ii) when the merger of two SMEs creates a firm too large to be classified as an SME, the new entity can nevertheless maintain the legal status of SME for three years.

51. In addition, the legal process for M\&As is being deregulated. Currently, M\&As must be approved at a shareholders' general meeting. But in the case of M\&As achieved through the issuance of new shares that amount to less than $10 \%$ of the merging companies' shares or through the acquisition of old shares amounting to more than $90 \%$ of the merged company, the M\&A will now need only to be approved by the board of directors. ${ }^{9}$ The government will also provide financial support for M\&As involving venture businesses. For example, the newly-established Growth Ladder Fund of 2 trillion KRW (\$1.9 billion) will provide financing to firms that do not qualify for bank loans, while the KCGF will provide guarantees of up to 100 billion KRW (\$96 million) for private financing.

52. Third, the government established the Korea New Exchange (KONEX) in July 2013 to ease the difficulties of start-ups younger than three years by significantly relaxing the requirements for listing and disclosure. For example, the number of mandatory disclosure items was reduced to 29 compared to 64 in KOSDAQ. KONEX is also aimed at smaller companies, requiring firms to only meet one of three listing conditions: i) sales revenue of more than 1 billion KRW ( $\$ 963$ thousand); ii) capital of more than 0.5 billion KRW; or iii) profits of more than 0.3 billion KRW. In addition, the preferential tax incentives currently given to investors in KOSDAQ will be expanded for those in the KONEX. For example, in KOSDAQ, the capital gains tax is exempted for minor shareholders. For major shareholders, who own more than $4 \%$ of shares or shares whose value exceeds 4 billion KRW ( 1 billion KRW in the case of shares listed on the KONEX), a preferential rate is applied. If a venture capital fund buys new shares in companies that are listed in the KONEX that are less than two years old, corporate taxes on capital gains and dividends and the securities transactions tax will not be applied.

53. Fourth, the government will make KOSDAQ more open to ventures and start-ups. This exchange, which was originally established to support venture businesses, has been criticised as being illsuited for innovative companies hoping to raise capital due to its conservative management focusing on investor protection (MOSF et al., 2013). In 2012, only 21 new companies were listed in KOSDAQ, compared to 171 in 2001. To re-orient KOSDAQ toward helping venture businesses raise capital, its management will be separated from the Korea Stock Exchange (KSE), the main exchange, which lists mainly large firms ${ }^{10}$ and KOSDAQ's listing committee will include more specialists on technology to enhance consistency and professionalism. ${ }^{11}$ In addition to the change of management, the requirements for an IPO are being relaxed while not significantly reducing investor protection. For example, the minimum age requirement for firms (currently three years) and the period during which major shareholders should retain their shares (currently one year) will be reduced.

54. Fifth, the government hopes to establish a channel through which the capital and know-how of successful venture entrepreneurs can be transferred to new start-ups. When venture entrepreneurs re-invest

9. In the future, the thresholds will be eased, with the $10 \%$ criterion raised to $20 \%$ and the $90 \%$ criteria lowered to $80 \%$, to promote M\&As.

10. Initially, KOSDAQ was operated separately from the KSE before the two exchanges were merged in 2004 to enhance the efficiency of their operations. Since the merger, the KOSDAQ has placed greater emphasis on investor protection, reflecting the influence of the KSE.

11. Currently, the listing committee, which evaluates candidates to join the KOSDAQ, is composed of seven members who are selected randomly from a pool of 30 specialists in diverse areas. 
capital gains received from selling shares in existing companies, the capital gains tax on the sales is deferred until the entrepreneur sells the newly-acquired shares. In addition, the government aims to establish a fund for successful venture entrepreneurs who invest in new ventures. The fund was set at 100 billion KRW (\$97 million) in 2013, with the government providing up to $60 \%$ of that amount, with the remainder coming from the entrepreneurs.

\section{Expanding infrastructure for venture businesses and start-ups}

55. The government's plan includes measures to improve the infrastructure for venture businesses and start-ups, in part by diversifying start-up platforms so as to connect people's imagination and creativity with start-ups. For example, the government launched the "Infinite Imagination Start-up Platform" in July 2013, a type of crowd-funding that allows potential entrepreneurs to propose ideas that are then voted on by the on-line community. Those with the winning ideas can start a business or sell the idea to someone else and share the profits with the company that purchases it. The objective is to provide help to potential entrepreneurs with design, marketing and production. The programme will begin with 30 to 40 projects in 2013 and expand to 100 in 2014.

56. Measures to attract human capital to venture and start-up companies are also being pursued. One option is to deregulate stock options, which at present are available only to the employees of a venture business, by extending them to employees of other companies in which a venture business owns more than $30 \%$ of the shares. The objective is to allow venture businesses to retain the human talent in companies that it acquires through M\&As. In addition, government research institutes will be encouraged to co-operate with venture businesses and to establish firms using their own technology and ideas. The Technology Transfer Promotion Law requires them to set up separate TLOs to promote technology transfers to SMEs. To better tap foreign technology, visas will be extended to foreigners willing to start a business in Korea. This initiative is modelled on the Start-up 3.0 Act in the United States. Although the visas are for only two years, they can be renewed if the foreigners continue doing business in Korea. Moreover, start-up visa holders who stay in Korea for three years or more, attract investment of at least 300 million KRW (\$289 thousand) and hire two or more Korean citizens are eligible for permanent residency.

57. The government will also take measures to protect the technology of venture businesses and startups and prevent piracy. The "Technology Deposit Safe" system, which allows SMEs to store technologically-valuable items, such as design drawings, in public institutions, will be expanded, making it easier for SMEs to prove their ownership of technology. Between 2008 and 2012, 3777 items were registered. In addition, the "Intellectual Property Rights Fund", which buys patents and technology from SMEs and then licenses the rights back to the SMEs, will be doubled from 100 billion KRW to 200 billion KRW (\$193 million). One advantage is that the Fund can fight piracy more effectively than individual companies. To fight illegal use of technology, all cases will be reported to the Prosecution Service and those violating the law will be subject to higher fines.

58. To promote entrepreneurship, new efforts by entrepreneurs who have failed will be encouraged. The government will expand the "Restart Support Fund", which is exclusively reserved for failed entrepreneurs who want to launch a new company, from 40 billion KRW in 2013 to 100 billion KRW (\$96 million) in 2017. In order to prevent CEOs of start-ups from personally falling into default, the practice of requiring joint liability as a condition of receiving credit was forbidden for banks in May 2012 and the KCGF and KOTEC are no longer allowed to require joint liability in the loans that they guarantee. This regulation was extended to non-bank financial institutions in July 2013. Finally, the credit recovery of entrepreneurs who are already personally delinquent will also be supported. In Korea, financial institutions register the delinquency of their borrowers on the public information system of the Korea Federation of Banks, which shares the information among financial institutions. Financial institutions are now allowed to cancel the registration after reviewing such factors as the feasibility of the CEO's plan for credit recovery. 
These changes have boosted Korea's ranking in Doing Business 2013, where it now stands $14^{\text {th }}$ out of 185 economies on the ease of resolving insolvency.

\section{Policy recommendations for improving financing for SMEs and venture businesses}

59. The rapid growth in bank lending to SMEs seems to suggest that government policies to promote financing for small firms have been effective. Indeed, SMEs received 78\% of business loans in 2011, one of the highest shares among OECD countries for which data are available (Figure 15). However, this has been achieved through a high level of government guarantees at more than $6 \%$ of GDP that has limited the development of market-based financing. In addition, the vast array of government support programmes result in a significant degree of waste and duplication, as well as unintended negative consequences, while the financing of ventures and new start-ups remains inadequate. Improving the financing of SMEs and start-ups requires a comprehensive approach that is outlined below.

\section{Reverse the upward trend in government support for SMEs}

60. Excessive and poorly-targeted government intervention is causing negative side-effects, such as hindering the timely restructuring of non-viable SMEs and impeding the development of the SME financing market. Given market failures, a government role in SME financing is necessary, especially in the case of start-ups and venture businesses, where the information asymmetry is particularly severe. In principle, the level of public financing support for SMEs should depend on the financing gap, i.e. the difference between the amount of SME financing that would occur in the absence of market failures and the actual amount of financing, although this is difficult to calculate in practice. ${ }^{12}$ However, the focus of SME policies in Korea has expanded from correcting market failures to promoting new growth engines, enhancing social cohesion and overcoming economic crises (KDI et al., 2011). This has boosted the level of support, including public guarantees, which are the second highest among OECD countries (Figure 4). Narrowing the focus of SME support to correcting market failures and closing the funding gap would reverse the rise in SME financing.

Figure 15. Korean SMEs account for a large share of banks' corporate lending

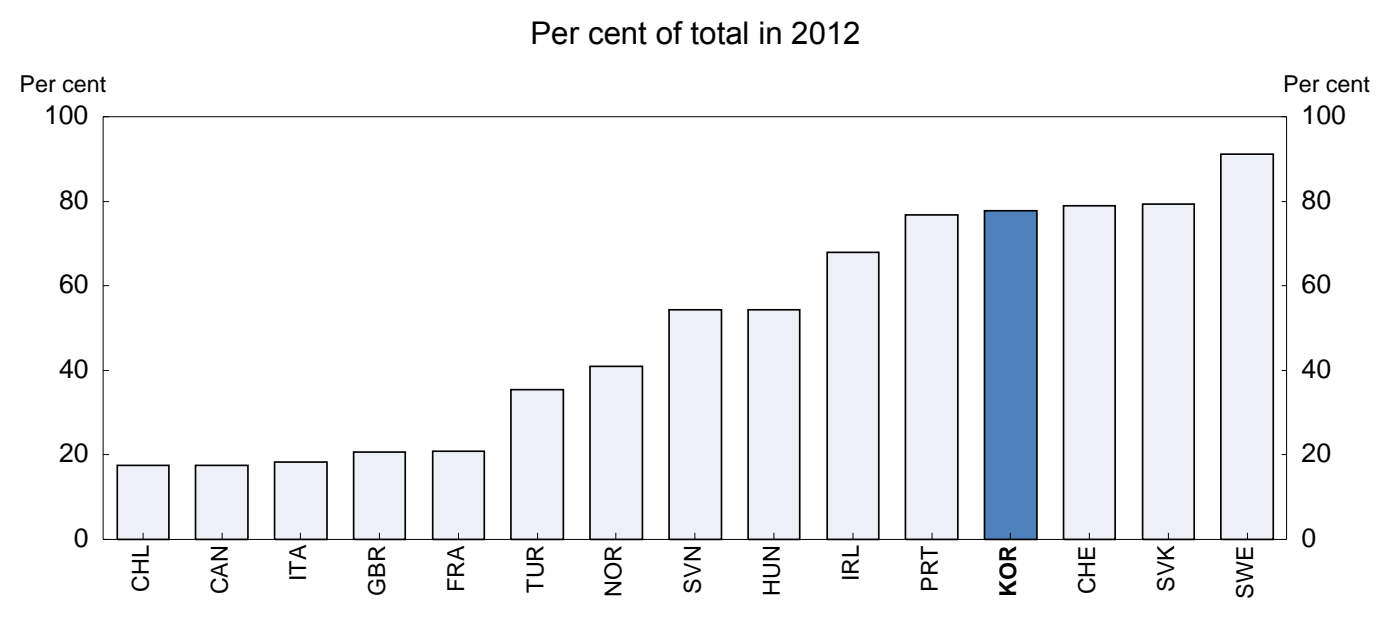

Source: OECD (2013b).

12. In the United Kingdom, for example, the government estimations the size of the financing gap, by calculating the financing needs of SMEs that are too big to borrow from micro-finance institutions but too small to borrow from regular private banks. 


\section{Improve the quality of government programmes for SMEs}

61. Narrowing the focus of government programmes for SMEs on filling the funding gap would also enhance their positive impact. At present, the government targets both efficiency - addressing the market failure - and income inequality. The focus on equality, rather than on selecting the most promising firms as beneficiaries, reduces the benefits of government SME programmes. Indeed, the negative impact of loan guarantees by the SMBC and KCGF on recipient firms' sales performance and the lack of a positive impact on profits (Table 3) indicates that firms are selected with little regard to their growth potential (KDI et al., 2011). The better results of firms guaranteed by KOTEC suggest that a review of technology plays a useful role in determining the allocation of guarantees.

62. In addition, the quality of government programmes should be improved by reducing the share of public support that goes to mature SMEs in an effort to ensure their survival. Instead, support should be concentrated in areas where the risk of market failure in ensuring financing is greatest, notably for start-ups and venture businesses at an early stage of development. As SMEs mature, their average default rate declines. Moreover, they accumulate business records and develop a relationship with financial institutions, enabling them to obtain financing without government assistance. In Europe, most countries impose a ten-year limit on public guarantees and, in some countries, it is as short as five years (OECD, 2013b). To ensure that SME support is focused on young firms, Korea should introduce a graduation system to prevent individual companies from receiving long-term support. In addition, the price of guarantees paid by SMEs should increase over time to discourage long-term reliance on public assistance. To ensure a focus on younger, smaller firms, the differentiation in the price of guarantees by the size of the loan that it is guaranteed should be expanded. Finally, it is also important to reduce support to firms that have relatively high credit ratings and can thus obtain financing by themselves. However, differentiation of the guarantee price by the level of firms' credit ratings may be counter-productive as it would make it cheaper for highly-rated firms to obtain government support.

63. The quality of government programmes would also be improved by making them more marketoriented. For example, the on-lending scheme, which draws on the knowledge of private financial institutions, should play a more important role. Public credit guarantee programmes should also be made more market-oriented by reducing the coverage ratio of credit guarantees to make banks active in monitoring credit risks. In OECD countries, loan guarantees typically cover $75 \%$ to $80 \%$ of the value of the loan (OECD, 2013b). While Korea has reduced the share from $100 \%$ toward its pre-crisis level of $85 \%$, KOTEC announced in May 2013 that it would provide 100\% guarantees for some loans. Finally, the interest rate on government lending to SMEs should be raised closer to market levels, so as to limit the crowding out of private financial institutions.

64. Another priority is to streamline the large number of government programmes for SMEs to reduce duplication and overlap. Such consolidation has been undertaken in a number of countries, including the United Kingdom (OECD, 2014a). In Korea, the SMBA is launching the "Comprehensive Management System for SME Support", which will collect information on all SME programmes. This system should be used to determine which individual firms receive multiple benefits from government programmes, thus indicating overlap. In addition, the Ministry of Strategy and Finance is strengthening the performance evaluation of programmes, which should be used to determine budget allocations. Rigorous ex post analysis should reduce the inefficiency caused by overlapping and duplication and avoid mismatch in the demand and supply for SME support programmes. A sunset clause should be attached to each programme as part of the effort to continuously streamline SME support. Finally, there should be prior consultations among ministries whenever any ministry proposes a new programme, with the Ministry of Strategy and Finance serving as the gate-keeper. 
ECO/WKP(2014)58

\section{Strengthen the infrastructure for market-based SME financing}

65. While providing public financing and credit guarantee to SMEs may be necessary, the government should develop the infrastructure for SME financing to enhance the role of private financial institutions. This requires improving the infrastructure for credit evaluation of SMEs, which requires the collection and analysis of both quantitative and qualitative information. However, the costs for financial institutions to collect and analyse such information generally exceeds the expected gains. To fill the gap, the government and public organisations involved in SME financing can help them by developing their own databases and sharing their information and experience with private financial institutions. The Korea Enterprise Data (KED), which was established in 2005, is playing the role of a credit bureau for SME financing. Public financial institutions, including the KCGF, KOTEC and SMBC, as well as nine private financial institutions, are shareholders in the KED. The role of the KED should be encouraged through information sharing to avoid the problems that occurred in the household lending market (Jones and Kim, 2014). The lack of proper credit evaluation and infrastructure for supporting it was a major cause of the massive defaults on household loans in 2003-04 (KIF, 2013). Financial institutions responded by centralising information on delinquent household debt and making it available to all financial institutions, thereby laying a solid foundation for a further expansion of household loans. For SME lending, a similar effort is needed, supported by the government and public institutions.

66. Financing based on long-term relationships between SMEs and financial institutions should be encouraged, as it can help overcome the problem of information asymmetry and facilitate lending. In order to expand relationship financing, financial institutions should strengthen their local presence and decentralise decision-making, given that many SMEs are located in rural areas. Decision on SME loans, which are relatively small, should be delegated to regional and local offices rather than the Seoul headquarters. The role of certain non-bank financial institutions (NBFIs), such as saving banks and credit unions, in lending to viable SMEs should also be encouraged. By nature, they are local financial institutions and their business model is rooted in relationships with individuals and firms in specific areas. ${ }^{13}$ Many NBFIs are searching for a new business model. As banks moved into SME and household lending after the 1997 crisis, NBFIs have had trouble competing and many responded by moving into risky lending, such as project financing. As a result, many NBFIs have been financially weakened by the sluggish real estate market and need to be restructured. ${ }^{14}$ In addition, NBFIs are often criticised for blindly competing with large commercial banks, rather than making the most of their comparative advantage in relationship-based lending (Financial Services Commission et al., 2013).

67. The range of collateral accepted by financial institutions for SME lending should also be expanded. Real estate is typically used as collateral given that it is easily traded in markets, giving it a clear value. However, SMEs, especially start-ups, generally do not have sufficient tangible assets, although they often have intangible assets, such as technology and intellectual property. It would be beneficial for SME financing if such intangible assets could be accepted as collateral by financial institutions. A 2012 law created the legal foundation for SME financing on the basis of movables, including intangible assets, but there have been no loans thus far on the basis of intellectual property. Following the implementation of the new framework, 628 billion KRW (0.1\% of total SME lending in 2012) was lent on the basis of movable collateral, with about one-quarter categorised as "movable intangible collateral", primarily receivables

13. Saving banks were originally consumer finance companies. The government legalised those companies as regional financial institutions, which prohibits them in principle from having bank branches across provinces.

14. Since 2011, the number of saving banks has decreased from 105 to 91, while their assets fell by one-half to 43.8 trillion KRW at the end of June 2013 (Financial Services Commission et al., 2013). 
(Financial Supervisory Service, 2013b). It will take some time to make intangible assets an important form of collateral, given the difficulty of evaluating their value and selling them in the case of loan defaults. To promote greater use of intangibles, the authorities need to train and nurture specialists for evaluating intangible assets, establish a common collateral management system for banks and provide education and training for employees in financial institutions and SMEs. The FSC should also help financial institutions by establishing a clear inspection manual in order to reduce the risk of being punished by the regulatory body.

\section{Promote the venture business sector and start-ups}

68. The government's plan to promote start-ups and venture businesses requires expanding direct financing from capital markets, which play a very minor role in the SME sector at present. Greater investment-based financing, as opposed to bank lending, depends in part on the success of KONEX in fulfilling its role as an exchange for start-ups and avoiding the path of KOSDAQ, which moved away from its initial role. The key to the sound development of KONEX is to correctly balance investor protection and market dynamism. Excessive investor protection would make the market unattractive to companies and investors alike. On the other hand, inadequate investor protection would be harmful to the market's development as it would increase the risk of moral hazard, as well as illegal activities by listed companies. On the investor side, it could also lead to irrational investments and possibly a bubble, as occurred in the KOSDAQ in the late 1990s (2004 OECD Economic Survey of Korea). Disappointed investors, who were negatively affected by the burst of a bubble or bad behaviour by listed companies, would then leave the market. Therefore, a balanced regulatory stance is necessary.

69. Activating the market for M\&As is essential to promote venture capital investment by allowing investors to withdraw their capital at an early stage. As noted above, the M\&A market in Korea is relatively small and the share of M\&As by foreign firms in Korea is insignificant, reflecting in part the early stage of development of Korea's capital market and the negative attitude of management, labour unions and non-governmental organisations (Jones and Yoon, 2008). The government should follow through on its plans to promote M\&As through more favourable tax treatment, a relaxation of the legal regulations and some direct financing and credit guarantees to help jump-start the M\&A market. A successful launch of KONEX, supported by the plan to relax the legal requirements, would help promote M\&As, as well as IPOs.

70. Venture capital investment in Korea is one of the largest in the OECD area as a share of GDP (Figure 13), with public funds accounting for nearly half of the total. It is important to avoid an excessive supply of public funds relative to the number of high-quality investment projects, which would tend to crowd out private investment. Inevitably, a portion of such large public support goes to firms that are not really venture businesses. Moreover, the success of such public investment programmes depends on their design and implementation. The government's emphasis on a fund-of-fund approach, in which it invests in private venture capital firms rather than directly in start-up firms, has been identified as good practice internationally (OECD, 2014a). Such an approach is effective because it channels public funds through existing market-based systems (Lerner, 2010). In addition, public funds should be utilised where market failure in the private sector is evident, suggesting a focus on early-stage financing where funding shortages are most likely.

71. Rather than just providing financing, government investment should also focus on the growth of the venture capital market by ensuring proper incentives and supporting the development of the necessary quality, skills and experience among angel investors (Lerner, 2012). This class of investors is extremely important both in terms of the aggregate scale of their investments, which in some countries exceeds that of the entire venture capital sector, and the expertise, networks and close interaction that they bring to startups. Government support for business angels has been available in Korea for some time, including the 
eight matching funds managed by KFF. In addition, tax incentives, another tool used in Korea, have been found to increase both the number of angel investors and the amount invested (OECD, 2014a).

72. As government efforts to date have focused on providing funds to invest in venture businesses and start-ups and encouraging private investment, the biggest obstacle appears to be on the demand side. A number of countries are shifting the orientation of programmes to the demand side to enhance the quality of the investment projects proposed by venture businesses. The high level of public investment in Korea should be accompanied by policies that create an environment for outstanding entrepreneurs with highquality investment opportunities. Indeed, the development of the venture capital industry cannot proceed more rapidly than the creation of attractive projects.

73. Korea should proceed carefully with its plan to make crowd-funding a complementary source of funding through which new ventures can raise seed money from a number of small investors. Equity crowd-funding is used to raise money through relatively small donations from a large number of people, helping novice entrepreneurs obtain financing without red tape, thereby enabling them to save time and money (Ham, 2013). It thus creates a new channel for ordinary citizens to fund companies in exchange for shares in a business. Gaining hundreds of investors via websites could also increase online popularity for a start-up because investors would tweet and post about the company so as to protect their investment. By 2011, \$1.5 billion globally is estimated to have been raised, even though the legal and institutional framework is still in its initial stages. There are an estimated 700 platforms focusing on specific areas, primarily at an early stage of financing. However, crowd-funding's role as a source of SME financing is marginal.

74. There is little analysis thus far of this relatively new area of financial development, which raises some concerns. Most business angels spend considerable time and money on due diligence before investing, in contrast to equity crowd-funding, in which most investors are primarily members of the general public, creating the risk of fraud (Isenberg, 2012). In addition, entrepreneurs with poor proposals who are rejected by experienced investors after detailed due diligence might turn to equity crowd-funding (Forbes, 2012). From a company perspective, relying on equity crowd-funding would mean losing the guidance and networks provided by seasoned angel investors. In addition, an idea launched via the Internet is easily copied. For such reasons, equity-based crowd-funding is not currently allowed in most OECD countries, although active crowd-funding platforms exist in Belgium, France, Germany, the Netherlands, the United Kingdom and the United States (Ham, 2013). In the United States, the 2012 JOBS Act allows businesses to sell up to $\$ 2$ million of unregistered securities through crowd-funding, providing an exemption from Securities and Exchange Commission regulations. In addition, individual investment is restricted to $\$ 10$ thousand or $10 \%$ of the investor's annual income - whichever is less. The need for investor protection depends on the amount of money raised. If large sums are raised through individual investors through crowd-funding, stronger investor protection is needed, although this would negate the advantage of crowd-funding, i.e. less regulation. On the other hand, crowd-funding that consists primarily of small amounts, thereby distributing risks widely, requires less regulation to protect investors.

75. The framework for entrepreneurship is another important aspect of social infrastructure, especially for venture businesses. The tradition that those who fail in a business venture cannot have a second chance makes potential entrepreneurs hesitate to launch risky venture businesses and start-ups. In addition, the channels through which the experience and knowledge gained from past failure can circulate within the market are blocked, thus reducing the social benefit. The government should do what it can to establish an environment that allows entrepreneurs who experience "honest failure" to have additional opportunities to create new ventures, thus promoting entrepreneurship within society. In this regard, the abolishment of the practice of joint liability is welcome. 


\section{Ensure prudent supervision of SME loans}

76. Even though the delinquency ratio of SME loans has remained low, the authorities should pay close attention to risks within the SME sector. With domestic demand contained by high household debt and weak investment, the performance of SMEs is unlikely to improve significantly in the short run. This makes SMEs, whose debt ratio is already much higher than large companies, more vulnerable to external shocks. An improvement in the macroeconomic environment could also pose challenges by leading to a rise in interest rates, adding to the difficulties of SMEs with excessive debt.

77. However, it would not be desirable to abruptly reduce SME borrowing. A pre-emptive reduction in debt could generate a vicious circle of more SME defaults, prompting financial institutions to further reduce their exposure to SMEs. This would risk creating a sharp increase in defaults, as occurred when the credit card bubble burst in 2003. With an average capital-adequacy ratio above $12 \%$, well above the allowed minimum of $8 \%$, Korean banks appear financially strong, despite weak profitability. Given the risks associated with SMEs, however, they should be encouraged to maintain a large capital buffer.

78. Maintaining a large buffer to absorb the losses generated by delinquent SME loans would enable banks to focus on closing non-viable SMEs and restructuring troubled firms. Since the global financial crisis, the Financial Supervisory Service has required banks to carry out credit evaluations of SMEs every year and publicly announce the results. Based on the evaluations, banks are required to decide which firms must undergo restructuring (OECD, 2010). This practice should be continued to pre-emptively reduce risk and enhance the efficiency of asset allocation. In addition, government agencies, including the KCGF and the KOTEC, also need to reduce their credit guarantee to non-viable SMEs.

\section{Box 2. Summary of recommendations to promote the financing of SMEs and start-ups in Korea}

\section{Promote the venture business sector and new start-ups}

- $\quad$ Make the new KONEX a key player in funding start-ups, while ensuring adequate investor protection in KONEX and for crowd-funding.

- $\quad$ Activate the market for M\&As by addressing the obstacles that have kept it small.

- $\quad$ Avoid excessive public funding of venture capital investment that would crowd out private investment, rely on a "fund-of-funds" approach and focus public support on the early stage of a firm's development when attracting private investors is most difficult.

- Develop the demand side of the venture capital market, in part by using public institutions to enhance the quality of investment projects.

- $\quad$ Foster an environment that allows failed entrepreneurs to have second chances to launch start-ups.

\section{Make SMEs part of the creative economy}

Improve policies to finance SMEs

- $\quad$ Target public loans and credit guarantees on young firms and startups, which struggle most to obtain market financing, introduce a graduation system to prevent firms from receiving long-term support and reduce public credit guarantees to firms with a credit rating high enough to obtain market financing by themselves.

- $\quad$ Strengthen the market orientation of SME programmes by: i) raising interest rates on public SME loans closer to market levels; ii) lowering the coverage ratio of the guarantees; and iii) more clearly differentiating the price of guarantees based on their length and size.

- Improve the selection of SMEs that receive public support by focusing on firms with the potential to upgrade their performance by analysing their competitiveness and technological capacity. 
Strengthen the infrastructure for market-based SME financing

- Use the government's expertise to enhance the infrastructure for credit evaluation of SMEs by private financial institutions.

- Encourage a larger role for local non-bank financial institutions, such as saving banks and credit unions, in lending to viable SMEs.

- Develop the infrastructure for using non-tangible collateral, including intellectual property, for private-sector loans.

Reduce the number of government programmes for SMEs

- $\quad$ Reduce the generosity of SME support to weaken the disincentives for small firms to grow out of the SME category, thereby increasing their productivity through economies of scale.

- $\quad$ Gradually reduce the number of SME programmes through stronger ex post evaluation of SME programmes to focus the budget on those that are most effective and expand prior consultations among ministries before introducing new programmes.

- Use the "Comprehensive Management System" to co-ordinate SME programmes between ministries and prevent SMEs from benefiting from multiple programmes.

\section{Bibliography}

Bank of Korea (1998), Financial Statement Analysis for 1997, Seoul (in Korean).

Bank of Korea (2012a), Extended 2010 Input-Output Tables, Seoul (in Korean).

Bank of Korea (2012b), Financial Stability Report 2012, Seoul.

Bank of Korea (2013), Survey of Bank Lending Practices, Seoul.

Berger, A. and G. Udell (1990), "Collateral, Loan Quality and Bank Risk", Journal of Monetary Economics, Vol. 25, No. 1.

Board of Audit and Inspection (2012), Inspection Report: Overview of SME Financing Support, Seoul (in Korean).

Caballero, R., T. Hoshi, and A. Kashyap (2006), “Zombie Lending and Depressed Restructuring in Japan”, National Bureau of Economic Research Working Papers, No. 12129.

Financial Services Commission, Ministry of Strategy and Finance, Ministry of Knowledge Economy, Fair Trade Commission, Small and Medium Business Administration, Bank of Korea and Financial Supervisory Service (2008), Policy Measures for SME Financing Support, Seoul (in Korean).

Financial Services Commission, Ministry of Strategy and Finance, Ministry of Knowledge Economy and Small and Medium Business Administration (2009), Policy Measures to Expand Credit Guarantees to SMEs and Small-Scale Self-Employers, Seoul (in Korean).

Financial Services Commission, Financial Supervisory Service, Korea Deposit Insurance Corporation and Korea Federation of Saving Banks (2013), Policy Direction for Sound Development of Saving Banks, Seoul (in Korean).

Financial Supervisory Service (2013a), Direct Financing from Financial Markets in 2012, Seoul (in Korean). 
Financial Supervisory Service (2013b), Performance during the Past Year Following the Introduction of Loans on the Basis of Movable Collateral and Policy Measures to Promote It, Seoul (in Korean).

Financial Supervisory Service (2014), Domestic Banks' Substandard and Below Loans in the First Quarter of 2014, Seoul.

Forbes (2012), "Breaking down the JOBS Act: Inside the Bill that would Transform American Business", 21 March.

Ham, J. (2013), "Crowdfunding: Opportunities and Challenges", mimeo, OECD.

Hong, C. (2012), “SME Sector”, Reports for 2012-2016 National Fiscal Policy Plan: Industry, SME and Energy Sector, Korea Development Institute, August, Seoul.

Isenberg, D. (2012), “The Road to Crowdfunding Hell”, Harvard Business Review, April.

Jones, R. and M. Kim (2014), "The Multiple Dimensions of Household Debt in Korea and Policy Implications", OECD Economics Department Working Papers (forthcoming), OECD Publishing.

Jones, R. and T. Yoon (2008), "Enhancing the Globalisation of Korea", OECD Economics Department Working Papers, No. 614, OECD Publishing, Paris.

Kang, J. and A. Heshmati (2008), "Effect of Credit Guarantee Policy on Survival and Performance of SMEs in the Republic of Korea", Small Business Economics, Vol. 31.

Kim, J. and J. Koo (2010), "Enhancing the Efficiency of Financial Intermediary Functions of Financial Institutions", The Direction for Development of Korean Economy after the Global Financial Crisis, Korea Development Institute, Seoul (in Korean).

Korea Development Institute, Korea Small Business Institute and Research Institute for the Assessment of Economic and Social Policies (2011), In-Depth Study on Fiscal Programmes 2010: the SME Sector, Seoul (in Korean).

Korea Institute of Finance (2013), "White Paper on Household Debt” , Financial Report, 2013-01, Seoul (in Korean).

Korea Venture Capital Association (2013a), Current Situation of Venture Companies, Seoul (in Korean).

Korea Venture Capital Association (2013b), Venture Capital Newsletter, Vol. 83, October (in Korean).

Lee, G. (2013), "Current Situation of Venture Investment Market and Problems to Be Solved", Weekly Economic and Financial Trends, Vol. 3, No. 14, Woori Finance Research Institute, Seoul (in Korean).

Lerner, J. (2010) "The Future of Public Efforts to Boost Entrepreneurship and Venture Capital”, Small Business Economics, July.

Lerner, J. (2012), Boulevard of Broken Dreams: Why Public Efforts to Boost Entrepreneurship and Venture Capital Have Failed - and What to Do About It, Princeton: Princeton University Press.

Ministry of Finance and Economy, Financial Supervisory Commission and Small and Medium Business Administration (2005), Restructuring the Institutional Framework for SME Financing Support, Seoul (in Korean). 
Ministry of Strategy and Finance (2013), The Park Geun-hye Administration's Creative Economy Blueprint: "Creative Economy Action Plan and Measures to Establish a Creative Economic Ecosystem", June, Seoul.

Ministry of Strategy and Finance, Ministry of Science, IT and Future Planning, Ministry of Justice, Ministry of Trade, Industry and Energy, Financial Supervisory Committee, Fair Trade Commission and Small and Medium Business Administration (2013), Policy Measures to Create a Virtuous Cycle in the Venture Start-up Capital Ecosystem, Seoul (in Korean).

Noh, H. and H. Lee (2013), "Current Situation of Marginal Companies and Implications", CEO Report No. 13-8, Woori Finance Research Institute, Seoul (in Korean).

OECD (2006), "The SME Financing Gap: Theory and Evidence”, Financial Market Trends, Vol. 2006/2, OECD Publishing, Paris.

OECD (2010), OECD Economic Survey of Korea, OECD Publishing, Paris.

OECD (2012a), Financing SMEs and Entrepreneurs 2012: An OECD Scoreboard, OECD Publishing, Paris.

OECD (2012b), OECD Economic Survey of Korea, OECD Publishing, Paris.

OECD (2013a), Entrepreneurship at a Glance, OECD Publishing, Paris.

OECD (2013b), Financing SMEs and Entrepreneurs 2013: An OECD Scoreboard, OECD Publishing, Paris.

OECD (2013c), OECD Science, Technology and Industry Scoreboard 2013, OECD Publishing, Paris.

OECD (2014a), Industry and Technology Policy in Korea, OECD Publishing Paris.

OECD (2014b), OECD Economic Survey of Korea, OECD Publishing, Paris.

Small and Medium Business Administration (2013), Policy Measures to Promote Productivity of SMEs for Accomplishing a Creative Economy, Daejeon (in Korean).

Sohn, S. and D. Kim (2013), Tasks for the Development of SME Financing, Korea Institute of Finance, Seoul (in Korean).

Statistics Korea (2013), National Survey of Enterprises, Daejeon (in Korean).

Stiglitz, J. and A. Weiss (1981), "Credit Rationing in Markets with Imperfect Information", American Economic Review, Vol. 71, No. 3.

Yang, J., H. Noh and H. Lee (2013), Proposals for Enhancing Financial Support for SMEs, Woori Finance Research Institute, February 2013, Seoul (in Korean).

Yoon, S. (2012), Evaluation of SME Financing Support Programmes, National Assembly Budget Office, Seoul (in Korean). 
ECO/WKP(2014)58

\section{WORKING PAPERS}

The full series of Economics Department Working Papers can be consulted at www.oecd.org/eco/workingpapers

1161. Fostering inclusive growth by promoting structural change in the business sector.

(September 2014) by Rauf Gönenç, Oliver Röhn, Vincent Koen and Fethi Ögünç.

1160. Reducing macroeconomic imbalances in Turkey

(September 2014) by Oliver Röhn, Rauf Gönenç, Vincent Koen and Evren Erdoğan Coşar.

1159. Reinvigorating the EU Single Market

(September 2014) by Jean-Marc Fournier.

1158. An exploration of the determinants of the subjective well-being of Americans during the great recession

(August 2014) by Aida Caldera Sánchez and Caroline Tassot.

1157. Boosting the development of efficient SMEs in the Netherlands

(September) by Rafał Kierzenkowski and Jochebed Kastaneer

1156. Making the banking sector more resilient and reducing household debt in the Netherlands

(September 2014) by Rafał Kierzenkowski, Olena Havrylchyk and Pierre Beynet

1155. US long term interest rates and capital flows to emerging economies

(July 2014) by Eduardo Olaberria

1154. Productivity measurement with natural capital and bad outputs

(July 2014) by Nicola Brandt, Paul Schreyer and Vera Zipperer

1153. Reducing income inequality and poverty and promoting social mobility in Korea

(July 2014) by Randall S. Jones and Satoshi Urasawa

1152. Fostering a creative economy to drive Korean growth

(July 2014) by Randall S. Jones and Myungkyoo Kim

1151. Economic uncertainties and their impact on activity in Greece compared with Ireland and Portugal

(July 2014) by Jan-David Schneider and Claude Giorno

1150. $\quad$ Workplace stress in the United States: issues and policies

(July 2014) by Michael Darden

1149. Taxing the rent of non-renewable resource sectors: a theoretical note

(July 2014) by Julien Daubanes and Saraly Andrade de Sá

1148. Health, work and working conditions: a review of the European economic literature

(July 2014) by Thomas Barnay

1147. Making the best of new energy resources in the United States

(July 2014) by Douglas Sutherland 
1146. Improving well-being in the United States

(July 2014) by Aida Caldera Sánchez, Patrick Lenain and Sarah Fléche

1145. Deconstructing Canada's housing markets: finance, affordability and urban sprawl (July 2014) by Calista Cheung

Restructurer les marchés canadiens du logement: financements, accessibilité financière et étalement urbain (Juillet 2014) par Calista Cheung

1144. Women's role in the Swiss economy

(July 2014) by Richard Dutu

Le rôle des femmes dans l'économie suisse

(Juillet 2014) par Richard Dutu

1143. Overcoming skills shortages in Canada

(July 2014) by David Carey

Combler les pénuries de compétences au Canada

(Juillet 2014) par David Carey

1142. Trade patterns in the 2060 world economy

(July 2014) by Jean Chateau, Lionel Fontagné, Jean Fouré, Åsa Johansson and Eduardo Olaberria

1141. The Demand for Skills 1995-2008: A global chain perspective

(July 2014) by Bart Los, Marcel P. Timmer and Gaaitzen J. De Vries

1140. International migration: The relationship with economic and policy factors in the home and destination country

(July 2014) by Ben Westmore

1139. Gross earning inequalities in OECD countries and major non-member economies: determinants and future scenarios

(July 2014) by Henrik Braconier and Jenifer Valenzuela Ruiz

1137. Managerial capital and business $R \& D$ as enablers of productivity convergence

(September 2014) by Dan Andrews and Ben Westmore

1136. Long-term patterns of trade and specialisation

(July 2014) by Asa Johansson and Eduardo Olaberria

1135. Consequences of climate change damages for economic growth - a dynamic quantitative assessment

(July 2014) by Rob Dellink, Elisa Lanzi, Jean Chateau, Francesco Bosello, Ramiro Parrado and Kelly de Bruin

1134. Comparing the robustness of $P A Y G$ pension schemes

(July 2014) by Falilou Fall

1133. Overcoming vulnerabilities of pension systems

(July 2014) by Falilou Fall and Debbie Bloch 